A WILDERNESS DOG THE BIOGRAPHY OF A GRAY WOLF

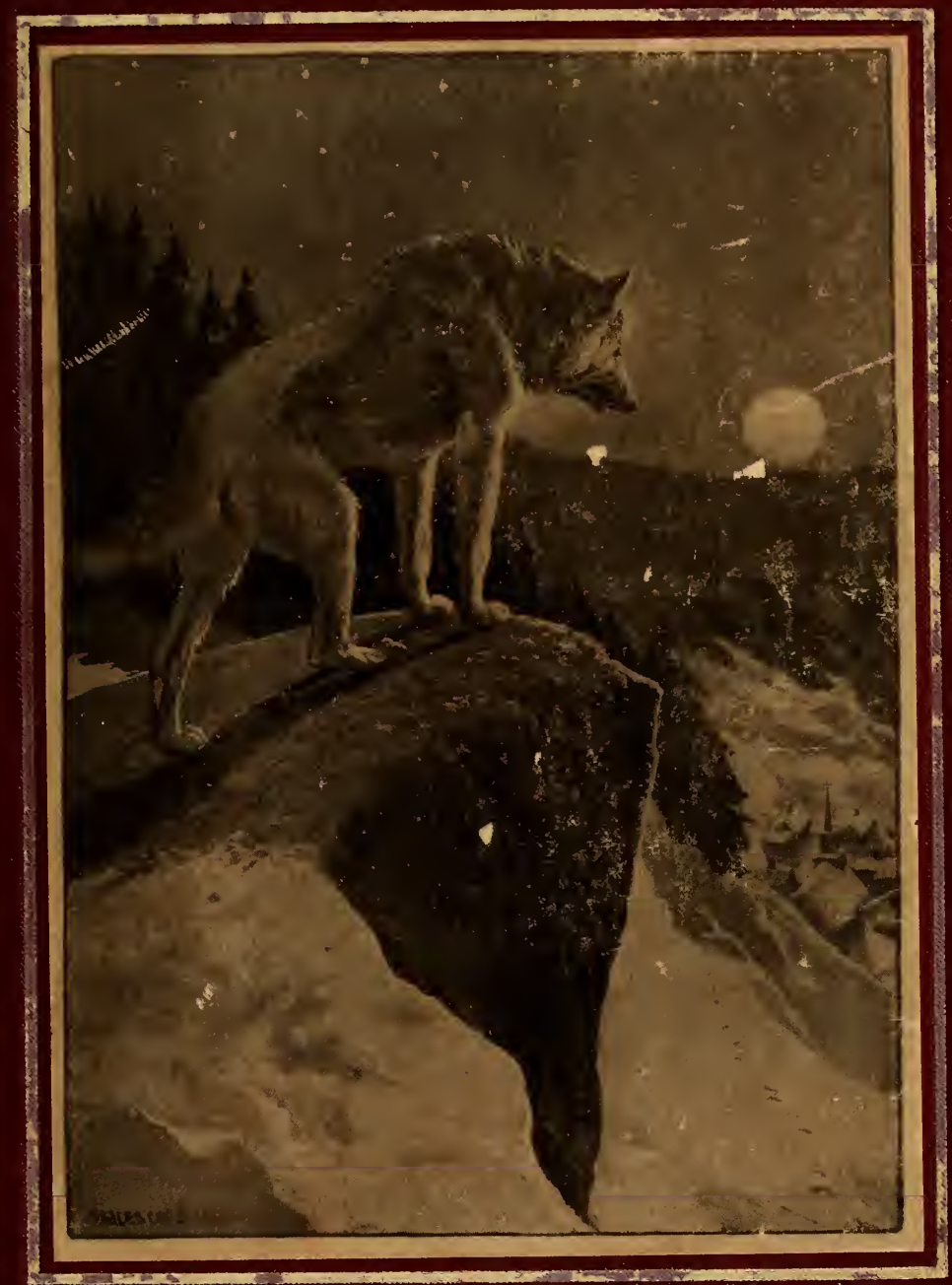

CLARENCE HAWKES 

A WILDERNESS DOG The Biography of a Gray Wolf 
t. 



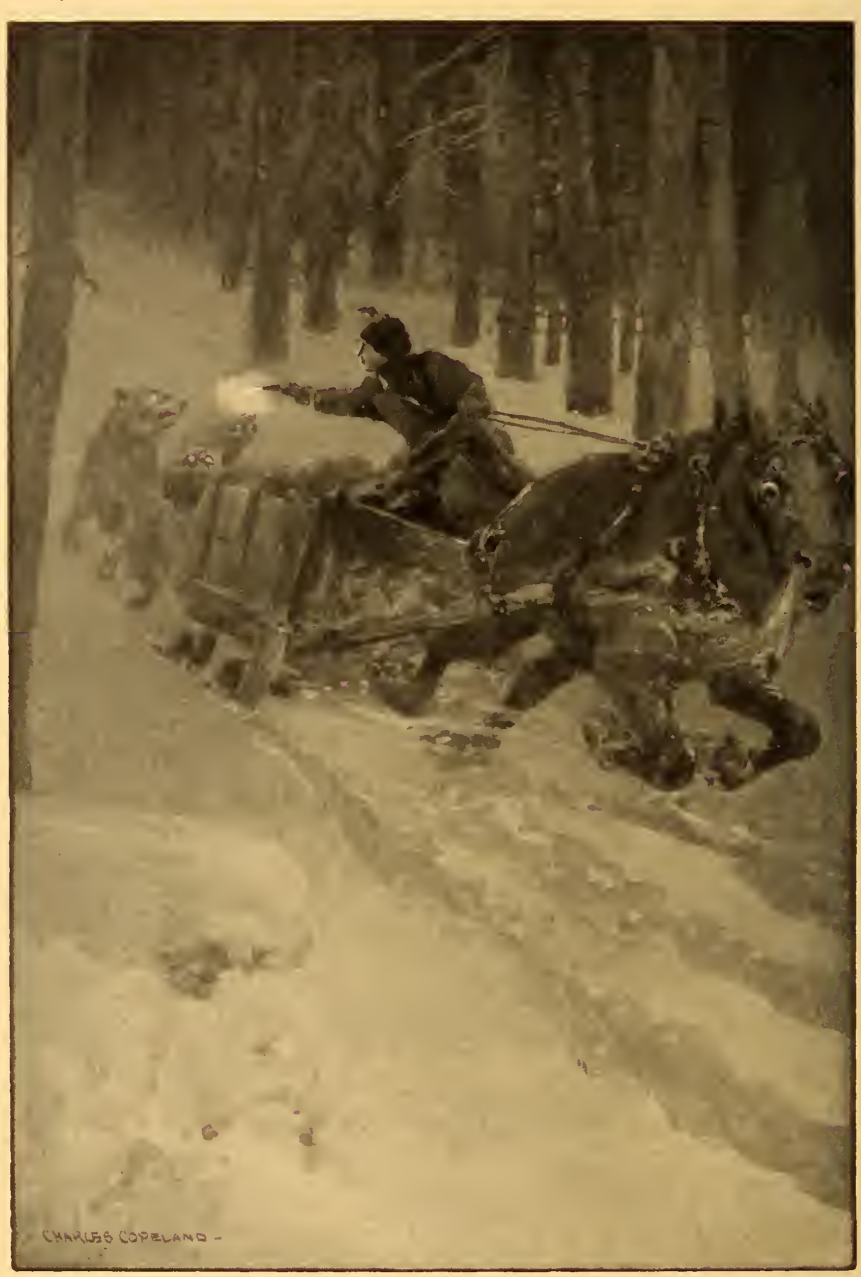

He Fired the Remaining Two Shots in His Revolver 


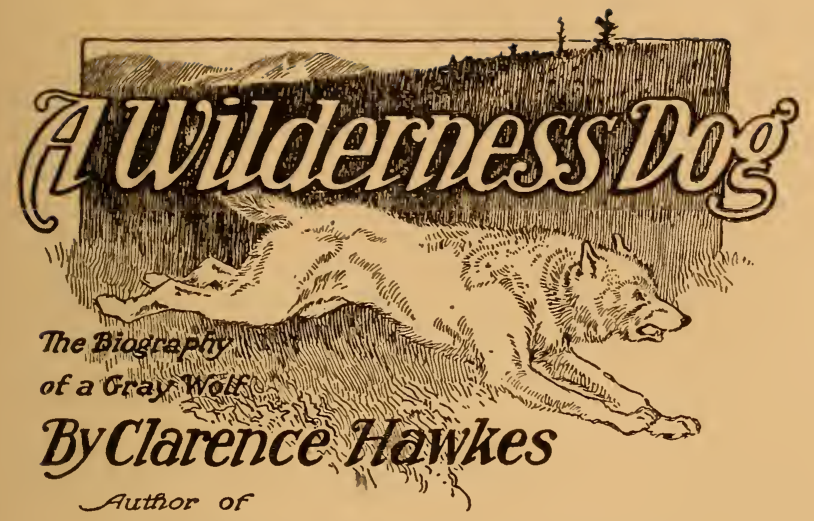

Shag'gycoat. the Biography of a Beaver Black Bruin. the Biography of a Bear Shovelfiorns, the Biography of a Moose

$$
\text { efc. }
$$

Illustrated by

Charles Copeland<smiles>c1ccc(C23CC4CC(CC(C4)C2)C3)cc1</smiles>

PHILADELPHLA

GEORGE W.JACOBS \& C:

PUBLISHERS 


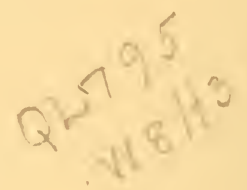

Copyright, 1910, by

George W. Jacobs \& Company

Published September, IgIo

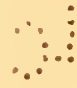

All rights reserved

Printed in U. S. A.

(C) $\mathrm{Cl}_{1} \mathrm{~A}: 15: 3$ 


\section{Dedicated to}

THE BOY CAMPERS OF AMERICA

little men of the out-of-doors, who fall asleep each night with their eyes upon the star-gemmed heavens, and wake each morning with the thrushes; who ripen in the sun, the wind and the rain, like muts upon the forest trees; and who catch something of the beauty and mystery of nature and hold it in their young hearts, like the morning dew in the chalice of the flower 


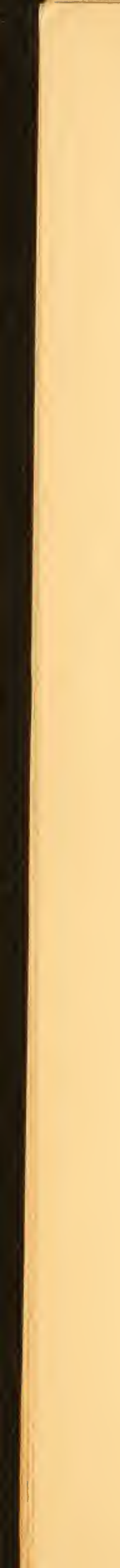




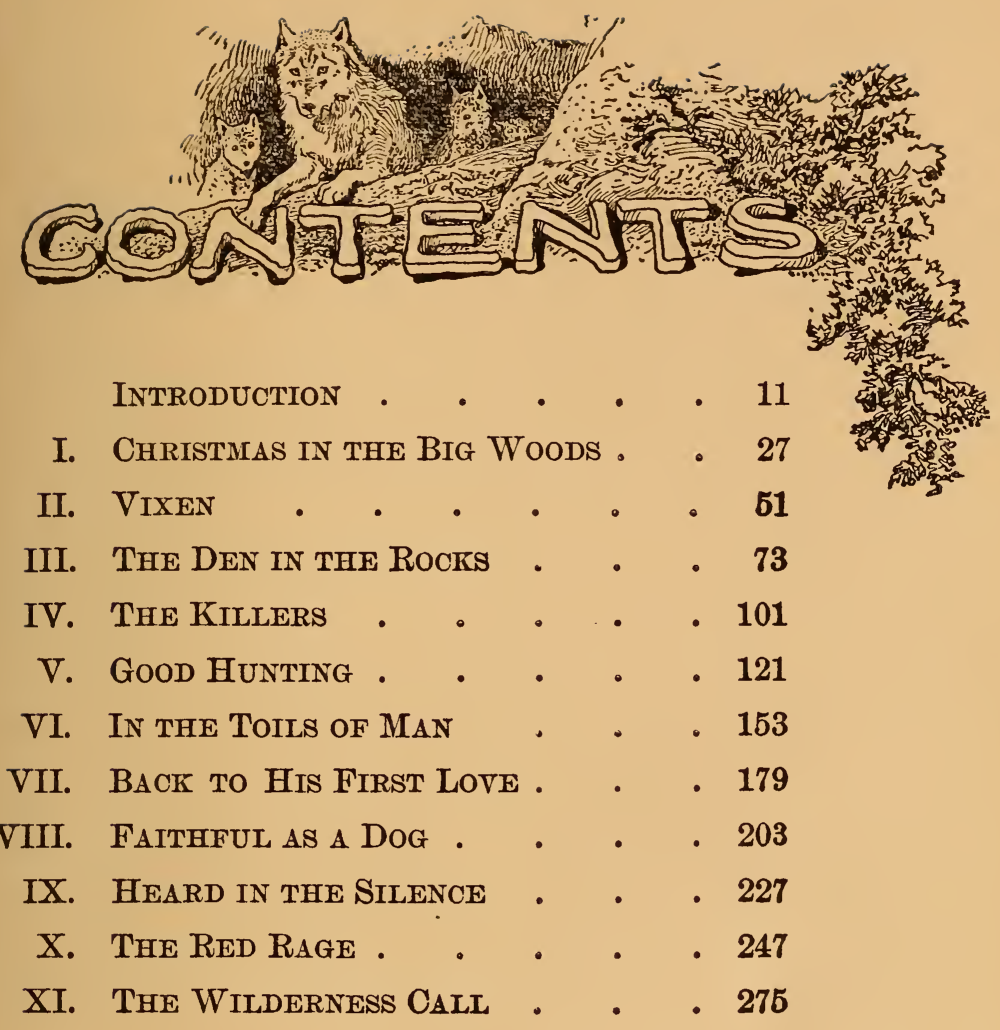





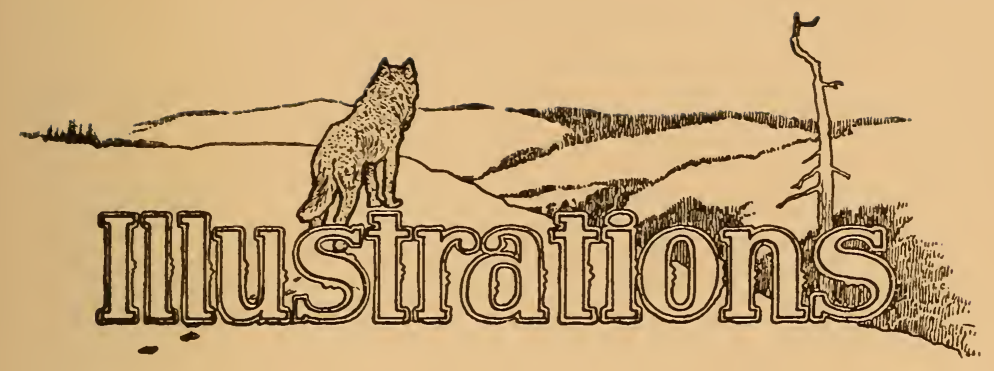

He Fired the Revaining Two Shots IN His Revolver . . . Frontispiece

They Started a Fine Buck out OF A Clump OF SPRUCES . . Facing page 128

HAIRFACE Sped to His IMPER. ILED MASTER • • • • 6 " 200

Frantically they Raced THROUGH THE SCORCHING WoODS • . • . 6 " 268

He GLOWERED DowN AT THE HOUSES OF MIEN IN THE VALLEY " " " 284 
INTRODUCTION 



\section{INTRODUCTION}

Into the folk-lore and the fireside tales of nearly all peoples has come striding the tall, sinister figure of the great gray wolf.

Sometimes it is in fairy stories as in "Little Red Ridinghood," which in Grimm's Fairy Tales is explained as a mythical legend, describing the alternate day and night and the daily disappearance of the moon (the grandmother) before the sun, which is the wolf. Again, it is in legend, as in the story of the founding of Rome by Romulus and Remus, through the kind maternal offices of their foster-mother, the she-wolf.

In still more startling form it comes to us from India in those gruesome tales of wolf children, and there seem to be many of them which are credited by Englishmen 
who know India and its people. Such a tale is Kipling's story of Mowgli, the fascinating yet fearful account of a child snatched from the fireside by a she-wolf and taken away to her den, where he was suckled and brought up in all ways like one of the wolf whelps, running either upon two feet or four at will, uttering strange cries like a wild beast, and eating flesh. Such is the description of the Indian wolfchild. But Mowgli became a great leader of the pack, supplementing the cunning of the wolf with that of man, and, whenever he could, preventing the pack from eating human flesh.

Nearly every people in its struggle on the frontier has fought with wolves; hence frontier literature abounds in accounts of hairbreadth escapes from them. Nowhere is this more true than in the literature of Russia, where the wolves are most destructive to human life. In many parts of that 
country the fight for existence against wolves is a desperate one, and the government bounties upon these gray marauders are very heavy.

In other countries the wolves content themselves with simply making raids upon sheep and cattle, or other stock, and are a very serious menace to the stock-raiser. This is particularly true in the northwestern portion of our own country, where continuous war has gone on between the stockraiser and the wolves ever since the days of Clarke and Lewis.

There have been many famous fighters in this border warfare;-wolves renowned for their strength and cunning who have set at naught the traps and the poison of men and their skill as hunters, and gone on year after year with their devastation. In such cases a wolf becomes legendary, and lives in fireside tales long after he has gone the way of his sires. 
Such a wolf was " the wild beast of Genendare," who terrorized Brittany in the north of France in 1760. He carried on his work of destruction among human beings for five years, although the skilled hunters of the country pursued him constantly, and notwithstanding the fact that the king had offered a large reward for his scalp, and for a portion of the time the better part of the French army was employed in hunting him.

In times of famine, wolves have been known to lay siege to large towns and not to allow the citizens to come forth for many weeks. But most of these strange things happened several centuries ago ; to-day the wolf is no longer a menace to life, and much less so to property than formerly.

The wolf is quick to learn from sad experience. Twenty or thirty years ago he could be both poisoned and trapped by the man upon our western frontier. To-day he 
knows both traps and strychnine and can be taken in neither way, so that man has again to sharpen his wits if he would protect his stock against the gray pack.

The wolf differs greatly in size, ferocity, and cunning, according to the region he inhabits, for it seems to be his environment that brings out his varying characteristics.

Naturalists are not of one accord as to the classification of wolves. All are agreed that there are two very distinctly marked species, but of the sub-divisions there seem to be many, all differing slightly, although not enough to render them really distinct from their brother wolves. The two widely differing varieties are the tall gray timber wolf, the scourge of the frontier, and his small brown brother, the prairie wolf, or coyote of the Mexican. These two are easily told apart in all climes, for one is a giant and the other, in comparison, a pigmy. 
Some of the very largest wolves on record are found in Colorado and in our northwestern states. Many of them tip the beam at considerably over one hundred pounds, and there are a few instances on record of wolves weighing one hundred and forty and one hundred and fifty pounds. One hundred pounds is a fair weight for a timber wolf, while a very large coyote does not weigh over thirty or thirty-five pounds. So the gap between these two wolves will be seen to be wide. From the coyote down, however, there seems to be a gradual and an easy grade to the fox, for there is a wolf in Mexico called the fox-wolf, who is the natural link between the two.

Again, the gray wolf varies in size and color according to the clime he inhabits. Usually he is a grizzled gray, tawny in places, and also with many hairs tipped with black; but in parts of Texas he is a dingy rufous red, while in another portion 
of the same state he is black. Along the upper Missouri River white wolves were quite common twenty years ago, so it will be seen that the gray wolf is not always gray. The coyote, which corresponds to the jackal in the eastern hemisphere, is nearly always some shade of brown; but he is a sneaking, no-account fellow, so it does not much matter what color he is.

In the cold winter months, when food becomes scarce, the wolves form themselves into packs of from six to twenty members and hunt their food in common. Then it is that the law of the pack, a rather simple though rigorous code, is in force.

The pack is always under the guidance of a leader ; the strongest and most cunning wolf has this honor. $\mathrm{He}$ it is who directs their movements, and exacts rigid obedience. If any transgress his law, their punishment is death, which the gray, grizzled veteran metes out himself, while 
the remainder of the pack look on with approval.

Male wolves are never allowed to transgress his laws, but females are shown more leniency. The reason for this is that a male wolf will rarely bite a female. No matter how much the she-wolf may exasperate her lord, he seldom punishes her; but simply turns his head and lets her slash him with her fangs at will.

Wolf whelps are simply a lot of tumbling, snapping, frolicking wilderness puppies. This is very easily proven. If one puts a collie pup into a wolf den, and allows it to be brought up with the wolf whelps, it will in one generation return completely to the wild, and when it has matured will be a veritable wolf, perhaps a little less ferocious than its real wolf brothers, yet to all intents and purposes a wolf. On the other hand, bring the wolf whelp into camp before he is old enough to have developed his wolfish 
traits, and you can make quite a respectable dog of him, although he will always be wolfish, and it would take several generations to make a clever dog of him.

Wolf-coursing has ever been a favorite sport upon the frontier, where the very conditions under which the people live breed recklessness and daring. In Europe it has been the pastime of the upper classes, and crowned heads have often distinguished themselves in famous wolf-hunts. Even to-day the Czar of all the Russias is supposed to own the finest wolfhounds in the world. Each year the royal family and the great retinue of the Czar go forth to test the skill of these Russian wolfhounds, and prizes are awarded to the best dogs.

Here, however, the sport seems to be rather cruel, as the dogs are run in packs and are taught to catch the wolf, each dog getting hold of a leg and stretching his body, thus holding him until the hunters come up. 
A few years ago an American gentleman imported some of these famous Russian wolfhounds, but they were entirely unable to make the American timber wolf submit to this stretching ordeal, as he seems to be stronger and fiercer than any of his brothers.

My father and an uncle went west in the early fifties, when Chicago was a small village, with rough plank walks and other primitive features. In those days, the farmers came to town, drawing their wheat in four-horse wagons. Some traversed a distance of one hundred and fifty miles over the prairies, and wolves often followed these teams for hours. When a small boy, it was my delight to sit at my father's knee and hear stories of wolves upon the great plains in the early days.

The most exciting of all these tales, to which I listened with bated breath, were the accounts of wolf-coursing, in which daredevil sport the men and boys indulged in 
the late autumn. The packs used in these hunts were usually a motley set of dogs: deerhounds, foxhounds, shepherds, bulldogs, and many varieties of mongrels.

The hiding-places of the wolves were in what is called the bottom-lands, along the river-courses, where there was timber which afforded them good cover. Unless you could find your wolf in the open, this cover had to be beaten and the wolf driven out. When he was at last sighted, pandemonium broke loose among both the pack and the horsemen, for it was a part of the game to make as much noise as possible, the theory being that this confused the wolf and prevented his making his best run. Shouts rang out, horns were blown, pistols were discharged, and away they all went at a frightful pace across the rough prairie.

About the only stratagem used was to keep the wolf in the open and ride hard. This riding was far more treacherous than 
that ordinarily indulged in by fox-hunters who hunt to hounds, for much of the way led through cities of prairie dogs, where the ground was fairly perforated with the burrows of these interesting little creatures.

With the horse going at a dead run, it was impossible to guide him and keep him out of danger; so he was usually given his head in any of this bad land, the rider knowing well that the horse's instinct was better than his own judgment in such a crisis.

Frequently after a long, hard chase, the wolf got away; but often he was at last brought to bay, and, amid a babel of snarling dogs, shouting men, and the crack of firearms, paid the price of being a wolf and an outcast of civilization.

The particular reason why I am interested in wolves and am writing this book is to show that the wolf is the wilderness brother of our friend the dog; that he is 
the dog's wild ancestor, like him in nearly every respect, but without his love and affection, which long association with man has so strongly developed. To me the affection of a good dog is one of the most beautiful things in the brute kingdom.

Just when or where the great gray wolf and man became acquainted is uncertain, but that they did become acquainted the dog can testify. It is probable that for centuries the wolf hovered upon the outskirts of man's camp-fire, fearful yet attracted, wishing to draw in close to this strange figure that crouched by the fire, yet not daring to do so. They met upon the mountain-top and in the deep valley, in spring, summer, autumn and winter, yet were strangers, until at last the fear wore away, and the great gaunt wolf drew in close to the man's habitation.

Perhaps he was hungry and the man threw him a fish, or it may be that the 
fascination of the firelight was too much for his curiosity; but at last he came and sat by the side of the man creature and finally snuggled up close to him, putting his long cruel muzzle into the hand of his master. Then he licked the hand of man, and has been his slave and admirer ever since, loving him through poverty and disgrace, in sickness and in health, eager to forgive an injury, faithful unto death as only a dog can be. Such is the trustful brute that has come to us from the pack of the gray wolf. 


\section{CHAPTER I}

\section{CHRISTMAS IN THE BIG WOODS}




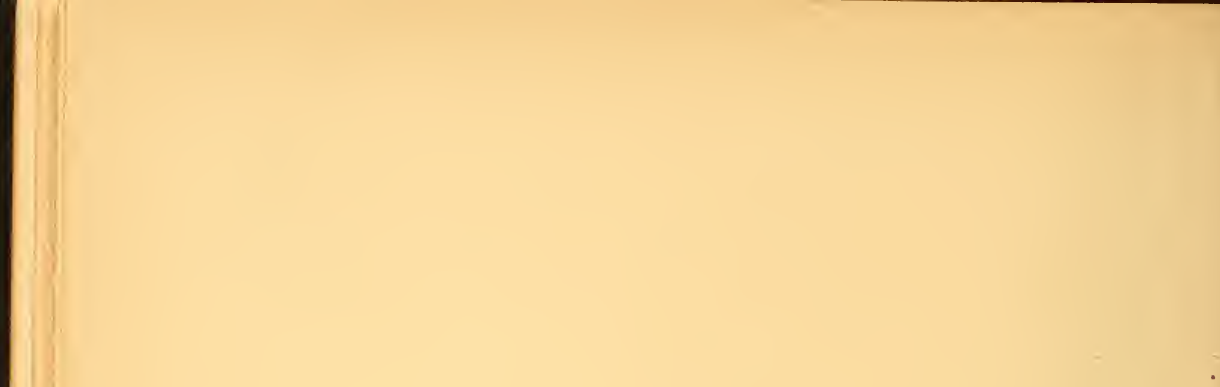




\section{A Wilderness Dog}

\section{CHAP'TER I}

CHRISTMAS IN THE BIG WOODS

IT was Christmas Eve in the big woods, but none of the silent-footed fur folk that came and went like shadows in its gray, ghastly aisles, or any of the swift-winged denizens of the tree-tops were aware of the fact. For them to-morrow would not be the very best and the gladdest day in all the year. To their senses the sun would shine no brighter, and the winds would be no warmer.

All day long they had come and gone, each upon his errand of subsistence bent. To catch somebody else, and not get caught himself,-that was the game. It was a 
rather hazardous game, but they had all of them always played it, and knew no other. If it was a hard lot, they did not realize it, for unlike man and the domestic creatures, they had not been pampered by civilization, and did not know the luxuries of shelter and artificial warmth.

But they played the game well, each in his own way.

The fox had gone about his hunting just as diligently that day as he ever had in his life, for game was scarce this winter, and the rabbit, the partridge, the wood-mouse, and everything else that is meat for Reynard had looked to it that this sly fellow went without his supper.

And each was well equipped to fight the battle. The rabbit had put on his ermine coat, that none of his many enemies might see him, and his broad-padded feet fell upon the snow, light as the falling of an autumn leaf. The weasel had also put on his white 
coat, which was unfortunate for all his prey both big and little, since it made him so inconspicuous in the new snow. The great horned owl had grown a fine fringe upon his wings, that his coming might be swift and sure; and the partridge, swaying in the tree-top as he budded, might not hear his approach or know of his whereabouts, until steely talons enfolded him.

Thus the old warfare went on, and it made no difference whether it was Christmas Eve or not. In the ancient woods the snows that had fallen thick and fast, ever since about Thanksgiving-time, were three or four feet deep. The laurel and the scrub spruces in many cases were entirely hidden. The rabbit swamps were a tangle of paths, main-traveled roads, and innumerable sidestreets leading in every direction. Here and there one could see where a buck rabbit had his rubbing-post upon a soft maple or a white birch. 
This was his own particular post, and for another rabbit to use it, would be as much a breach of etiquette, as for you or me to use another person's comb or brush. Impolite rabbits sometimes trespassed the long-established rules of conduct for the woods, and then there were battles royal, simply over a rubbing-post;-but men often fight over even smaller things than that.

Occasionally also one might see where a partridge had plunged under the snow, for a night's rest. Here it was that the prowling fox, who does most of his hunting at night, sometimes found the sound sleeper; then there were signs of a scuffle and blood upon the snow, and perhaps a few feathers, for Reynard is a sly fellow, else he would have starved ages ago.

Early that morning of December twentyfourth, just as the sun glorified the eastern hilltops, and set all the myriad snow-crystals in field and forest to sparkling, a tote-team 
had started from McGregor's Point, a small lumbering and trading town on the upper Ottawa River, to carry supplies to camp No. 18, of the Ottawa River Lumber Company.

The team was driven by Roderick McElwain, a vigorous Scotch boy of about eighteen years. The load was a few general provisions for the camp, and also the mail from the outside world, with many parcels brimming with Christmas cheer. In short, the load was a sort of Merry Christmas from the world to camp No. 18.

The trip was a long one, considering the fact that the snow was deep, and much of the way the team could merely wallow slowly; but in other places, where the pines and the spruces were especially heavy, the track was fairly good. Young McElwain had been over the trail every other day since the first snowfall, and although it was a winding, devious way, he knew all of its 
twists and turns, as well as you or I would know our own city street. This was his woodsman's instinct.

But the roads had never been as bad as they were to-day, and when the blue shadows of the early winter twilight began creeping through the woods, he had covered only about two-thirds of the journey, and there were still seven or eight good English miles between him and a night's lodging for both man and beast. This would not be so bad if the moon were bright, but there were signs of its being cloudy, and the outlook was not pleasant.

Anxiously Roderick watched the long blue shadows creep through the forest, and the sable mantle of night enfold the white landscape; but it was not with fear, for to his strong nerves the forest held no terrors. It was the inconvenience of plodding for miles upon a winding, twisting trail in nearly total darkness that bothered him. 
At first a few stars, brighter than their fellows, pricked through the haze, but even these were soon obscured by the enfolding gloom.

With the coming of night, the wind began to freshen and to moan a cheerless wailing dirge in the tree-tops. A benumbing chill also crept into the air, and altogether the night boded ill for the young traveler caught so far from shelter.

As the darkness deepened, he was obliged to go still more slowly and occasionally even to get out and hunt for the trail. This he was able to do, even in the darkness, by treading about in the snow, for the trail was hard, while the untrodden snows were very soft, and as soon as one got off the track he sank deep in them.

It was an eerie night of moaning winds and groaning branches, punctuated with the occasional hooting of an owl or the sharp bark of a prowling fox. 
Once the young teamster got a few feet off the trail, and it was with great difficulty that he guided his plunging, frightened horse back to safety. Just as he had found the trail once more, and was again plodding upon his arduous way, a long, desolate, high-keyed howl floated down through the aisles of the gloom-haunted forest. It was so thin, so wavering, and so much like the howling of the wind, that a less experienced ear than Roderick's might have been mistaken in the sound. But, although he had heard the cry rarely before, he knew it instantly as foreboding menace, especially to a lone traveler far from shelter. It was the hunting cry of the great gray wolf.

Presently the fitful wind again bore the wild, weird howl to his ears. At first he had been doubtful of the direction from which it had come, but now he located it without difficulty, for it sounded somewhat nearer. The great gray hunter was on his 
trail, after his flesh and that of old Benny, the tote-horse.

A few minutes before he had been debating the advisability of camping for the night; now, that was out of the question. $\mathrm{He}$ must press on desperately and see if he could not reach Lake Quambog before the fight came, for he was sure that there would be a fight. The deep snows had made hunting bad for the wolves, and they certainly were in earnest this time.

$\mathrm{He}$ reached under the seat to see if the thirty-two calibre revolver which he always carried was there, and, after reassuring himself that it was safe, braced his nerves, and urged Benny forward.

Soon the howling was repeated, this time much nearer,-so near in fact that it gave Roderick quite a start. They were following rapidly. Again and again the desolate, blood-curdling cry was reiterated, each time a little nearer. Like an inexorable fate, 
this menace from the seemingly peaceful woods bore down upon the young man.

Five anxious minutes dragged by, and the cries were not repeated. A less experienced woodsman than Roderick might have been deceived into the belief that his trail had been abandoned, but not he. $\mathrm{He}$ knew full well that their silence meant they had discovered his proximity, and were closing in, or reconnoitering their prey.

Another minute of this suspense went by and then old Benny stopped stock still in the trail and began snorting and shaking with fright. Roderick peered into the darkness, and, forty or fifty feet ahead, made out the two yellow phosphorous eyes of a wolf, burning like live coals.

This was serious. They had either intentionally or unwittingly got directly in his way, so that further progress was impossible until the road was cleared. Why could not the miserable brutes content themselves with 
following behind? Then they might even help him to urge the tired horse forward.

Roderick reached down under the seat for his revolver, and, turning Benny's head as far to one side as he could and still keep him on the trail, he took deliberate aim between the two bright coals and fired. The old tote-horse reared and plunged, and for a moment the boy had his hands full quieting him. When he got a chance to look for the wolf, the two coals had disappeared and the way was again clear.

Once more they started forward, but now Benny was keyed to the highest pitch. $\mathrm{He}$ too understood the danger, and that wild, unreasoning terror, which horses often show in time of peril, made him almost unmanageable.

For an arduous quarter of a mile they moved on again, the horse plunging and snorting, and the driver holding on to him for dear life, and, by a superhuman effort, 
keeping him in the path. Then Roderick's quick ear caught the soft patter of feet on the trail behind, and, turning, he made out three or four tall gray shapes following. How bold they were becoming! If they were not checked they might at any minute jump upon his low load from behind and attack him; so turning part way around, and at the same time keeping as tight a rein on the horse as he could, he fired one more shot at his menacing enemies. But the shot was probably high; and, although they all sneaked into the cover at the side of the trail and followed warily for a few rods, no harm was done them as far as Roderick could see. Soon he heard the rhythmic pat-a-pat-pat in the road behind, and knew that they were following again.

They were not as much of a menace from behind, however, as when they blocked his way in front, so he let them come on, until one caught at the end of a blanket that was 
flapping behind, and sought to pull it from the load. Then Roderick whirled and fired again. As before, they took to the underbrush, but not for long.

A bright thought now came to him. He reached down under the blankets and dragged up a ham, about the only eatable thing in the load, and threw it over the back of the sled, as a peace-offering to his pursuers.

The famished pack fell upon it like furies, and the boy shuddered at the thought of what they would do to him if they got the chance. But they were soon back, like Oliver Twist, asking for more. Roderick had no more meat for them, and little else that he fancied they would care for; but at last, seeing how hard they were pressing him, he hurled the buffalo robe at them, and it, too, went the way of the ham.

The lake was now barely half a mile 
distant, and the boy's hopes began to rise; if he could only reach it; he knew that he could offer a better fight. There the way was smooth and open, and if the moon would only come up, he felt certain that he could beat them off. So, as fast as the wolves pressed him too hard, he fired the remaining two shots in his revolver, and urged the frantic horse forward.

Yet the pack pressed him closer and closer, and he was soon obliged to strike with the whip and to shout, in order to keep them from springing upon the load behind.

The rearing and plunging of the horse did not permit of his loading the revolver again, and he now began to fear that he had made a mistake in not keeping his last two shots until they came to close quarters. He reached down under the seat and got out the axe which he always carried. That did not need to be reloaded, and, after all, 
was about as good a weapon at close range as the revolver.

Suddenly a mighty wolf leaped fairly upon the top of the load. At the same instant Roderick had a premonition of danger, and turned just in time to see the brute spring.

The axe was light, and the young man was strong, and his plight made him desperate. Before the wolf could advance or retreat, with a mighty blow he sent him sprawling in the road behind. It was a lucky blow well placed, and the fallen wolf's famished comrades, frenzied by the blood that flowed freely from a gash in his head, made short work of him.

For fifteen minutes Roderick and his jaded horse plodded on without molestation, and then he gave a great shout of joy. The moon was at last breaking through the clouds, and the lake, wind-swept and nearly free of snow, was just ahead. He had also 
reloaded his revolver during the cessation of hostilities, and now felt much better able to continue the struggle.

"Come on," he shouted, as the horse broke into a wild gallop across the frozen lake, " and I will give you a bit of lead for supper."

His pursuers needed no further invitation, and soon six gigantic timber wolves were racing over the ice after him.

Bang, went his revolver and the bullet skimmed over the ice. It was almost impossible to hit one of them, with his attention so closely riveted upon the horse, and going at this breakneck pace. Three of the brutes raced alongside and three behind, but Benny still kept up his frantic speed. Soon two alarming facts were apparent: first, that the horse was nearly exhausted; and, second, that the wolves were on the outside, running the team around in a great circle. 
When Roderick fully realized these two facts, his blood ran cold. Benny would soon drop, and they would be at the mercy of the pack. He cheered on the poor horse with friendly cries, and shouted hoarse imprecations at his foes; but in spite of all he could do, the pace slackened, and the great circle in which they were running grew smaller and smaller.

As long as they kept in rapid motion, Roderick did not much fear that the wolves would try to close in on him, but as soon as they came to a dead stop, then he knew that there would be a desperate battle. $\mathrm{He}$ would have to protect both himself and the horse, for he did not intend to abandon his faithful steed to these famished brutes.

After fifteen minutes of rapid running, the tired horse was blowing and gasping, nearly winded; but the gaunt timber wolves galloped on, as fresh as ever. Clearly it was no hardship for them. The 
circle in which they were now running was only about twenty rods in diameter, and at first it had been half a mile. Surely it seemed that the chances of escape upon the lake, which Roderick had thought so bright a few minutes before, were vanishing rapidly.

The wolves now galloped in close, and once a gigantic tawny fellow snapped at Benny's leg. Roderick shuddered to think how soon the pack would have been upon them, had the wolf drawn blood.

In a last effort to frighten them a little farther from the horse he fired his remaining two shots, and again his revolver was empty. Just at the moment that the last shot rang out clear and sharp upon the night air, a tall, gaunt figure leaped fairly upon the load behind him. Roderick felt the hot breath of the beast upon the back of his neck, so sure and strong had been the leap.

Quick as a flash he turned, raising the empty revolver to strike the wolf, who, he 
had no doubt, would give him a desperate fight for life.

The revolver fell, but not by his volition. Instead it fell from his nerveless hand by its own weight, and with a glad cry of both triumph and thanksgiving, he seized the great brute about the neck in a transport of delight.

"Vixen, old girl," he cried, "Vixen, you came just in time to get me out of a mighty tight place. Now we'll show 'em. Seek 'em, Vixen ; seek 'em."

The tall, sinewy Irish deerhound, who had come out of the distant camp, drawn hither by some subtle premonition of her master's danger, needed no further urging; for she was a famous wolf-dog and a terrible fighter. She sprang into the gap between the jaded horse and the pack, her hackles raised, her fangs bared, and her hairy face wrinkled into a devilish snarl.

As she stood there defending from danger 
those that she loved, she was a formidable figure. Three feet at the shoulders she stood, and she tipped the beam at one hundred and twenty-five pounds. There was not an ounce of fat upon her, but her muscles were like whip-cords, and her motions were as quick as those of a wolf.

At this new front, the pack drew off a few feet until they should inspect the new adversary, to determine her fighting qualities, and the horse slowed down to a shambling trot.

Roderick now reloaded his revolver, and felt safer. His luck had changed and a minute later with a deliberate aim he knocked over the leader, a grizzled dog wolf. Seeing his advantage, he sent shot after shot into the pack. This soon demoralized them and they sneaked off across the ice into the shadows of the forest, leaving Roderick and Vixen in full possession of the field. 
When the last skulking gray form had disappeared, Roderick hugged the great deerhound with sheer delight; but they lost no time in getting the team turned about and started for camp, which was barely a mile from the edge of the lake.

Vixen mounted guard on top of the load, where shestood with raised hackles, growling and menacing, as much as to say: " Keep your distance, you sneaking gray cowards. I am protecting the load, and any one that harms it or my master will have to settle with me."

Twenty minutes later, the tote-team, with the great gray hound still mounting guard, came into camp, and Roderick narrated his escape to an excited group of lumbermen.

"Mighty close call, Rod," said Dugan Campbell, the boss, when he had heard the boy's story. "That dog's intelligence does beat the world. You will all remember how she came to me last winter when I 
broke my leg in the windfall. She always seems to know if a man is in trouble. About half an hour ago, boy, she got excited, and whined and scratched at the door, and nothing would do but she must go outside, and as soon as I let her out, she put off through the woods as though the devil was after her."

"The devil was after me, and not her," laughed Roderick. Now that the trouble was over he could afford to joke about it, especially as he had come out of it so well.

Then there was supper for both man and beast, and after that sweet sleep in a warm bunk in the long, low room; but you may be sure that Vixen was the heroine of the camp for many a day. 
CHAPTER II

\section{VIXEN}


the

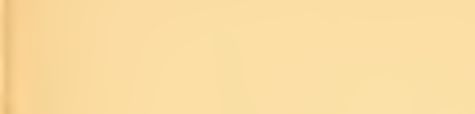




\section{CHAPTER II}

\section{VIXEN}

From that night when the tall Irish deerhound came to the aid of the beleaguered driver of the tote-team, a strong friendship sprang up between Roderick and the dog. They had always liked each other, but this tussle with the wolves seemed to cement the bond of friendship between them, just as men upon the battle-field become the best of friends in a few hours.

The dog had not really belonged to Roderick; but, as the manager of the lumber-camp who owned her was his uncle, he had always spoken of the hound as his. After this adventurous night, seeing the growing intimacy of the two, Mr. McElwain gave Vixen to Roderick outright, and the two celebrated the occasion of the transfer 
by a long snow-shoe tramp through the winter woods.

Still another sign of attachment was also noticed: the hound now always went to meet her new master on his return from the Point, which occurred every other day. She seemed to have some sixth sense that told her when the tote-team was within two or three miles of the camp.

The hour of Roderick's return was quite irregular, depending upon the condition of the trail. Sometimes it was three or four o'clock in the afternoon, often it was not until nine o'clock at night; but the dog always hit it just right. Half an hour before the team finally appeared in camp, she would start out, and her master would soon return with the hound riding triumphantly on top of the load.

The coarse lumbermen in the camp were not to the dog's liking, and she would tolerate no familiarity on their part. If any 
one transgressed the bounds of propriety, he was soon told, by raised hackles and bared teeth, to keep his distance; but if a lumberman was drunk, the dog seemed to understand, and would not bite him, no matter how much he offended her. This rarely occurred, however, as all liquors were denied the camp, and it was only when spirits were smuggled in that they were to be had at all.

Every morning when the men tumbled out of their bunks, the hound would also arise from her bed in the stables, stretch herself, and come into the mess-room for breakfast, for she was quite one of the large family. This was before light, and there was great activity in camp, especially in the cook-room and at the stables, where men and horses were being fed. Vixen took her mess of beans and corn bread as soberly as any one.

If you pointed your finger at her and 
smiled or laughed, her dignity would be offended. If you were a stranger, she would become so infuriated that your mirth would at once cease; but, if you were a friend, she would slink into some dark corner and leave her breakfast unfinished.

When the men and teams went away for the cutting and hauling of logs, she either stretched herself by the fire and slept, or went on long hunting-trips in the snowladen forest.

These were busy days in the woods, and mournful days for one who loved the forest.

The keen double-bitted axes were swinging and ringing all day long, and every few minutes a forest giant, that had withstood the elements for a hundred or perhaps two hundred years, would be seen to totter, and finally, with a rush of wind, a crash like thunder, and a cloud of snow, 
would fall like a wounded warrior among its already denuded fellows.

All day long the saws kept up their monotonous song of wee-waw, wee-waw ; while busy teamsters guided straining horses drawing logs to the skidway. Each man and each team had its particular task, and all did it with dispatch.

There was little talking or jesting; all were too engrossed in their work. Besides, inattention meant danger to life and limb. A moment's heedlessness on the part of a driver or a cant-hook man, and a huge log, weighing tons, would get away and perhaps crush some one in the tumble. There was also a menace in the continually falling trees. Often as the trees fell great limbs broke off and lodged in tops of other trees, unnoticed by the woodsmen. Perhaps a day or a week later, this limb would come hurtling down upon some unsuspecting head. Peaceful as the scene 
appeared, with the green plumes and white snow, there was danger on every hand.

You have merely to look into the face of a lumberman to read this eternal vigilance that is the price of safety in the camp. His eyes are alert, his ears are alert, his muscles are tense and alert, and his whole organism is ready to spring this way or that at a second's notice.

It was amid such busy scenes of the lumber-camp in the heart of the wilderness, that this friendship between boy and dog was formed, so perfect in its understanding that the lumbermen often said that Vixen knew what her master was thinking just as well as he did. Certainly, if watching his every movement could have given her the cue to his thoughts, she possessed them in full.

In February, there came warm weather with occasional thaws that sometimes made the trail impassable for several days. Then 
the two occupied their time hunting and tramping the wilderness. Finally, about the first of March, the logs were cut and all hands turned their attention to helping the teamsters and the cant-hook men, for the spring rains and high water would soon be on, and every log must be at the river in time for high water.

The logging-camp was about half a mile from the right branch of the upper Saganal, which had been enlarged at this point by an ambitious dam. Into the lake made by this dam, thousands and tens of thousands of logs had been shot. It was intended all should be there when the dam was blown up with dynamite and, with a rush and a roar, the great log-drive was started upon its way down to the Ottawa River.

One crisp morning the first week in March, Vixen arose from her snug nest in the corner of the stable earlier than common, yawned, stretched her muscles, and, 
going to the stable-door and forcing it open, trotted off through the gray gloom of the forest, without even waiting for her breakfast. The morning passed and she did not return, and, when the tote-team came in at night, for once she was not waiting on the road to greet her master. This was not all ; for neither that day, nor that week, nor that month, did she return; in fact, she was never seen in camp again.

It is with her strange disappearance from camp and her subsequent life that this story is now immediately concerned; so let us follow her through the spruce gloom to her uncommon fate.

The night before, while the lumbermen slumbered, a silent figure as tall and as muscular as that of the great hound stole through the camp and at last came stealthily to the stable-door. Here it paused for several moments until its good nose made it conversant with the contents of the stable. 
At first the nose was confused by the many odors, but finally after sifting them and analyzing each one, the stranger knew that the Irish deerhound whom he had seen the night of the fight upon the lake was sleeping in the corner near by.

Once sure of this fact, he began sniffing and scratching softly. Instantly the hound awoke and stood on guard with raised hackles and bared fangs at the other side of the strong plank door. But the stranger on the outside still continued to sniff and the hound's anger subsided.

I do not know that they appointed the tryst then and there; but certain it is that finally the gray wolf went away, and the hound went back to her corner, and that she disappeared the following morning before the camp was astir.

She seemed not to be uncertain of where she was going, but took a straight track across country through labyrinths of swamp, 
over high bluffs, and across deep gorges, where only instinct could guide her.

After two hours of steady trotting, she came out on the top of a high bluff and saw the tall gray wolf waiting for her. Perhaps she had expected this or perhaps it was a mere accident. However that may be, after bristling and growling at her old enemy, the deerhound went up and sniffed noses with him, and after a few more preliminaries, the two trotted off into the forest, going side by side, apparently well satisfied with each other's company.

Thus it happened that the tall hound obeyed an instinct which was as strong now as before the wolves ventured into the camp of man and became dogs. A wolf she was at the first; so was it any wonder that occasionally the wolf nature reasserted itself, and the dog went back to the wild, especially when the dog kin were far away in the distant settlements? 
The woodsmen laughed at Roderick, who was half heart-broken over the loss of his old friend. At first he swore that she would return in a day or two; she had merely gone on a long hunt and would soon come back.

Each night, upon the return trip from the Point, he fully expected to see her loping along the trail to meet him, as had been her custom ever since the fight with the wolves on the lake; but she never came, and each night he drove into camp dejected and lonely because of his loss.

Meanwhile Vixen and the old gray wolf, whose kind she had hitherto fought with a mad fury, hunted and romped together, and the former enmity between the dog and its wild brother was forgotten, or rather there was a truce in favor of this particular wolf. When another dog wolf did appear one day, Vixen flew at him with all the old fury, and drove him frantically from the 
vicinity, thus proving her dog fidelity to the old tradition of hatred. But the dog wolf did not turn upon her, true to the law of the pack, which does not permit a male wolf to fight with a female.

By the first of April the last of the logs had been sent down the chute and out upon the lake, and the spring rains came down in torrents. Then the lumbermen broke camp, a part of them going back to the Point with the teams and camp equipment, and the rest going with the drive.

It was a week or ten days, though, before the ice was really out of the river, and the dam was dynamited. Then there was a sight to make mere men shiver and hold their breath, when the elements, for months chained in ice behind the stout log dam, ran mad, and spent the fury that had been so long pent up.

A considerable portion of the dam gave way. The waters roared, foamed, and 
hissed; the logs leaped and tumbled, smashing into one another like batteringrams; and the entire lake, filled with millions and millions of feet of timber, seemed suddenly energized, and of one accord the drive began grinding on its way toward the Ottawa. The infuriated waters sucked and whirled, tugged and pushed, while the logs groaned and tumbled, fought and butted like living things. There were dull thuds and sudden sharp cracks resembling those of a rifle, as the whole scene resolved into a mountain of tumult like that of the glaciers of old.

Above and about this terrible, grinding, death-dealing monster, leaped excited men. They stood upon the logs as they swayed and rushed. They leaped from point to point like mad men. Danger seemed to them to be of little moment so long as the avalanche of timber went grinding upon its terrible way. 
In the commotion due to getting the drive started, Roderick for the first time forgot the loss of his dog friend; but when, a month later, the drive was safe out in the branch, and well on its way to the mills, he gave up his job and went back to the scene of the winter's camp to seek Vixen.

It was so forlorn a hope to find the faithful dog when over two months had elapsed since her disappearance, that Roderick said nothing about his real errand to his friends; but merely gave out that he was going on a fishing and camping expedition. This was partly true, as the trout were already biting freely in the ice-cold waters and the camp was a necessity in this wilderness. $\mathrm{He}$ took a small rifle, some fishing-tackle, and a hatchet, "going light," as a woodsman would say.

For a week or so he lingered in the region of the lumber-camp. Now that the snow was gone, the devastation made by the 
lumbermen was even more apparent. There were great piles of sawdust everywhere. Jagged stumps and tree-tops piled mountain high made a desolate scene, when one thought of the tranquil forest with its phalanx of woodland giants that had been there the spring before.

It was something of a solace to the boy's wounded spirit to be alone in the wilderness, but day after day went by and he was no nearer his quest. It had been a wildgoose chase anyhow, he thought, for the dog was dead or she would have returned to him long ago. This had been his own conclusion, and it was merely on the suggestion of an old trapper that she had gone off with the wolves that he had come back to look for her.

One day about the middle of May, when he had been in the wilderness for two weeks, Roderick was fishing in a deep pool of a turbulent stream, just beneath a fall, 
when his attention was attracted by a violent crashing in the thicket near by. He had not even time to conjecture what might cause such a commotion, when the head of a fine buck flashed through the thicket and was gone; but by the swaying of the bushes he could follow the buck's course in his mad flight.

While the boy was still wondering what made the deer in such a hurry, the form of a great gray wolf slipped rapidly through the cover in pursuit. Roderick's sympathies were immediately aroused in behalf of the buck. He dropped the fish-pole, seized his rifle, and hurried to a point where he thought both the buck and the wolf would leave the cover and give him a chance for a shot; but before the deer reached the open, something happened that quite changed his calculations.

Suddenly from the cover, the buck was seen to give two or three gigantic leaps; 
then there was a great thrashing and crashing and a groan from the deer as though his heart were being torn out of him.

It was useless trying to wait for the shot in the open, which might come too late. He might hit the buck, but he would frighten his assailant at least. This reasoning was done in a flash, just as the woodsman always thinks, and then Roderick sent two bullets into the cover in quick succession.

The result was most satisfactory. At the shots, the buck, apparently freeing himself from his pursuer, came into the open, leaping and snorting, and Roderick had the satisfaction of seeing him make good his escape, for no wolf followed him.

When the blowing fugitive had disappeared, the boy reloaded his rifle and went into the cover to see what effect, if any, his shots had taken. He had marked the spot where the struggle had occurred and had no difficulty in locating it. In the midst of 
the thicket he stumbled upon a mighty wolf gasping in the last death-throes. But no, it was not a wolf, it was a dog. Then a wild, heart-broken cry came from the boy's lips as he gazed, horror-stricken, upon the prostrate figure.

It was Vixen, his own Vixen, that the bullet had found; Vixen gone back to the wolves and turned venison killer. Roderick knelt beside the dying dog and held her head in his lap, unmindful of the blood that dripped freely upon his hunting-shirt. He caressed the hairy face, and fondled the long ears, and the old hound licked his hands in forgiveness of the fatal shot. So, by the cruel caprice of fate, the faithful dog, who had come to his aid in his hour of peril, was laid low by her master's bullet, and he could do nothing but pour out his heart's love in broken sentences, as the light of intelligence and love faded from her eyes, until she at last stretched out dead at his feet. 
For more than an hour he sat there perfectly motionless, although he knew that the deep chest no longer drew breath. This was his last act of love, of atonement for the mistake which was the fault of neither. Then, with his hatchet and some sharp sticks, he dug a grave, that her mate, the great gray wolf, might not find her, and covered her with the cool sweet earth which is the winding-sheet of dog and man alike.

But this was not until he had noted that her breasts were swollen with milk; a fact that Roderick well knew meant a litter of wolf-dogs somewhere in the vicinity, who would now starve unless he could find them, and thus there would be a double tragedy on his hands. 



\section{CHAPTER III}

\section{THE DEN IN THE ROCKS}




\section{CHAPTER III}

THE DEN IN THE ROCKS

WHen the old he-wolf saw his mate fall, kicking in her death struggle, he understood at once the danger at hand. It did not need the crack of the rifle and the scent of powder, or that most repugnant of all scents, the man taint, to tell him that he was upon perilous ground. His perceptions were so fine that he even knew this particular man to be he whom the wolves had hunted that winter's night upon the lake.

Then, as now, this man creature had been most destructive of his kind, so he melted like a gray shadow into the deepest of the cover, and Roderick did not see him again.

There is a great difference among wild 
creatures in the manner of their getting out of sight in time of danger. The bear goes blunderingly, making considerable racket, but the members of the cat family slink away as silently as shadows. Most dogs are more or less noisy in going through thick cover, but their brother, the wolf, has caught the cat habit of slinking, and his neutral color helps him to disappear readily.

When he had gained a sufficient distance from the cover to permit it, the old wolf broke into his accustomed lope, and did not stop until he had put several miles between himself and the scene of the tragedy.

That night when the moon was high above the eastern hilltops, he came back and went carefully over all the ground, beginning with the man's footsteps at the pool where he had been fishing. He followed the scent thence to the spot where the deerhound had fallen, and near by he dis- 
covered a fresh mound of dirt. His good nose told him that his dead mate was buried beneath. To make sure of this, he dug down a foot or two, until he could touch her cold, lifeless nose, after which he carefully scratched back the dirt.

In time of famine, or even moderate hunger, he would have eaten her; but his belly was full, so the grave in the thicket was not profaned. $\mathrm{He}$ then followed Roderick's trail back to his camp, and there sat upon his tail for an hour, watching the embers of the dying camp-fire.

At last he went away, and an hour later the young man was roused by a series of long-drawn, desolate howls; howls that rose and swelled in mighty volume until they filled the listening woods. Although they came from the throat of a wolf, yet were these cries the very embodiment of grief, anguish unspeakable, mournful as the minor cadences of the wind and the waters. 
Finally the sounds so disturbed Roderick that he got up and rekindled his camp-fire.

"Gol durn it. I wish he would shut up," he muttered. "Any one would think to hear him take on that he felt as bad about it as I do."

After a while, to the boy's great relief, the cries ceased. The old wolf in his grief had bethought him of the litter of wolf whelps. He did not know just where the den was situated, for his mate had guarded this secret well, but he knew about where it was.

The mother wolf is usually very jealous of her young and does not reveal their place of hiding to her lord ; partly because many males, including the big cats, have a rather horrible habit of eating their offspring if they find them before they get their eyes open. After the young have reached the frolicsome stage, they will not molest them. The male deer will also frequently kill the 
fawn, especially if it happens to be a male. Even at that tender age, he probably recognizes a possible rival.

It took but an hour of diligent hunting, assisted as he was by his good nose and his keen instinct, for the old wolf to locate the den. He went in and lay down beside the whelps, who at once crowded into his flanks to nurse. This made the old wolf nervous and immediately suggested the disadvantage he would experience in feeding the pups. Fortunately they were five or six weeks old and could be shifted to a meat diet if it was a question of starvation.

At sight and scent of the wriggling whelps, the old wolf's responsibility pressed hard upon him. He had hunted food for his mate for the past few weeks, but the immediate mothering had not been his, and now the new difficulty troubled him.

Of one thing he felt certain. This country was not a safe place for his offspring, so he 
picked one of them up in his great jaws, and trotted off with it into the outer world to which the whelps had never penetrated. Half an hour later he came back for another, and still later for the third; so that, when the new day dawned, the family had shifted its abode several miles to the northward, where the country was still more wild and rugged.

It was providential, from the wolf's standpoint, that he did so, for Roderick, too, was searching for the litter of wolf puppies, and by a mere chance found the den on the second day of his search; but it was quite empty. This was a great disappointment to him, as he had hoped for a whelp that he might atone to it for the unlucky shot which killed the mother. The signs in the wolf den were perplexing. It might not be the right den after all, although he felt sure it had been inhabited by wolves recently. Perhaps the real den was somewhere near by, 
and Vixen's puppies were doomed to slow starvation. So much did this idea work upon the boy's feelings, that he spent still another day searching; but was finally obliged to give it up, and go on to the logdrive, which by this time was far down the river.

About the new den which the old wolf had selected for his family, he kept vigilant guard. For two days the whelps refused to change from a milk to a meat diet, but necessity finally conquered.

At first the wolf despaired of finding anything that they could eat, but he happened upon a sitting of partridge eggs, and these delicacies seemed to give the whelps just the start they needed. In a few days they were eating mice and squirrels, and even the partridge whose eggs had served them in good stead.

There were two things about the whelps that greatly distressed their guardian, and 
that was their whining and whimpering when hungry, and their continual nestling when he approached them. For his own part he was dignified and quiet, and so much commotion was extremely annoying.

$\mathrm{He}$ was often absent from the den for hours, and when he pretended to be at home, he usually lay outside, watching with his yellow, all-seeing eyes everything that moved within the radius of his vision. $\mathrm{He}$ would lie so quiet that he might have been a great gray rock, or almost anything rather than a mass of intense muscles and sinews; a body alert, hungry, terrible in its destructive powers.

To the whelps in the den, the new quarters were very much like the old. Both were dark, and, so far as they were concerned, equally suited to their needs. One is not particular when he spends most of his time sleeping. As they grew older, however, this habit, with which all young 
things seem to be born, was less and less persistent, and they sometimes spent an hour tumbling and rolling about, chewing one another's ears, closing upon one another's throats in imitation of the death grip that in later life would be so important.

The best quality of the den was that it was dry, so, no matter how cold and wet it was outside, this ball of wriggling wolf whelps was always warm and comfortable. The den had many sharp points and angles, and also holes and hummocks. Into one of these near the nest a pup would often roll, and there he would lie upon his back, kicking and whimpering, not knowing how to get out of the dilemma. He would continue to struggle until at last by a desperate effort he would get upon his feet, and then set himself the task of climbing out of the hole. The cries of his mates who missed him from the nest would give him the right direction and he would finally get safely 
back, probably feeling that he had been upon a long journey, and had had quite a narrow escape.

Three sides of the den were black, and hurt when one ran his nose against them. The fourth side was whiter than the others and one could go much farther in this direction than in any other. If he ventured too far, however, there was usually a warning growl from the old wolf on guard. The whelp venturing near the mouth of the den usually interpreted this growl as meaning, "Go back or I shall nip you," and the pup always obeyed.

A sharp little nip was the form of punishment that the old wolf used for correcting the habits of his offspring. The nip was generally administered when a whelp worried him, or was too noisy; but he left them as much alone as possible, for both their outcries for food and their romping made him nervous. 
One day the largest and most courageous of the whelps went farther and farther toward the light at the mouth of the den. The old wolf was off hunting, so the warning growl was not given. Step by step the pup went forward, until at last he stood in the mouth of the den in the full blaze of the morning light. The sun was so bright and his young eyes were so long used to semi-darkness that he winked and blinked, and was finally forced to shut them. He also felt that this extreme light was a menace, a danger, so he growled fiercely, and ruffled up the hair on his neck; he would frighten this strange brightness away. When he opened his eyes, it was still there, so he growled again, a deeper and fiercer growl than before. Still it persisted. By this time he was getting used to the light; it did not hurt him as he had expected, so he finally ceased his growling and looked about. 
Away in every direction stretched the strange whiteness, and the outside world was so large and new that it terrified him; he slunk back toward the dark, again growling. But by degrees he came forward again, and at last got used to the largeness of the outer world, just as he had to the light.

Step by step he crept, until at last he reached the edge of a shelf, which fell off sharply two or three feet to the ground beneath. This was the old wolf's favorite seat, and the whelp as he sat there was a very good miniature of his sire.

To him holes and hummocks looked very much alike. His eyes had not learned perspective, or to discriminate between earth and atmosphere. He felt just as confident that he could walk upon the air beneath the shelf as upon the solid rock, so he took a step forward. As a consequence he went headlong over the edge of the rock, and 
rolled over and over, at last bringing up at the bottom with a thump that made him "ki-yi" with might and main. These sounds sent his two companions, who were also investigating the light, scurrying back to the nest, where they cuddled closely together for mutual protection. What dreadful thing had happened to their brother? Would it come to them next? How far away he sounded! Was the old wolf punishing him? These were the things that they must have thought, if they thought at all.

Meanwhile the adventurer, at the foot of the rock, soon discovered that he was not killed, ceased his whimpering, and sat up, looking about him at the great world. When he had been upon the shelf within easy reach of the den, he felt quite safe; but now a strange terror seized him. He was so far from home and his nose was bleeding. Altogether he was a sorry sight 
as he cowered against the rock, waiting for he knew not what.

Presently a great gray shape loomed up in the bushes near by, and the whelp, perceiving it, squeezed up closer to the rock that he might not be discovered. Even at that early age the trick of hiding from all that was strange asserted itself. Wolves liad hidden and slunk from danger for so many generations, that this whelp, half wolf and half dog, did it instinctively, as part of his hereditary knowledge.

Still, he did not escape the notice of the great gray figure. With a snarl, it sprang forward, and strong jaws seized the culprit by the scruff of the neck. Then the two whelps cowering in the den heard a "ki-yiing," beside which the cries that their brother had uttered when he fell were tame. The old wolf shook the cub until it seemed as though he would slip out of his rather loose skin. The poor little offender flopped 
this way and that, his legs and ears snapping and his loose joints fairly outdoing themselves for flexibility.

Finally, with a growl, the like of which had never been heard in the den before, the old fury sprang inside and deposited the culprit, too spent now even to sob, beside his brothers, and stood growling over the three. The fate of the one was to be a warning to the others. This would be their lot if they ventured to the outside world as he had done. The punishment had been so terrible that the three never forgot the lesson, especially he to whom the correction had fallen. From that day he was the best behaved of all the litter.

About a week after the mishap to the venturesome whelp, the old wolf came forth one morning and reconnoitered very carefully, circling about the den in all directions, and testing the wind critically with his good nose. He seemed satisfied that no 
danger lurked near the den, and went back to its entrance. There he stood waiting for a few seconds and then two of the whelps came creeping into the outer world. They had never dared to do this before or even to approach very near to the mouth of the den. Yet here they were coming out into the sunlight, apparently unbidden. The old wolf had made no sound, but they evidently understood that they had his consent at last.

Any farm-boy who has lain in the grass and watched an old fox bring forth the foxkits to play will tell you that the mother fox rarely utters a sound in governing them. If they stray too far into dangerous cover, she will simply look at them, and the little foxes will be seen to hesitate as though they feel the call, but cannot locate it. Then they will turn, and seeing their mother, hurry back with an apologetic air.

It was by some such signal as this that the young wolf whelps knew that the griz- 
zled wolf, their father, had given permission for them to come forth. The last of all the litter to take advantage of the invitation was he who had first ventured out on his own account; when he did come, it was with hesitation, as though he hardly dared to believe the good news, after his recent sorry experience.

The great bright world must have looked like an endless space to the winking, blinking cubs as they huddled together or crowded about the old wolf. After the novelty had worn off, the guardian of the litter would not allow them to come near him, but preferred that they should explore and learn of the outer world for themselves. He sat upon his haunches while the whelps went creeping, with many halts and feints, from point to point; but at the slightest sound they started and came scurrying back to him.

Now that they were out in the open, one 
could see what they looked like. One of the whelps had bred as a perfect wolf, with the markings and build of a wolf. One was a very fair cross between his sire and the old Irish deerhound, for he had patches of brown sprinkled through his coat, and was taller and more rangey than his brothers. The third whelp was a perfect wolf with the exception that his face was covered with the long coarse hair of the deerhound.

The old wolf seemed troubled by the looks of the second pup; perhaps he did not understand the patches of brown; at least there was something about this offspring that displeased him. At first he had half a mind to disown the whelp, and growled savagely whenever the unfortunate one came near. He finally seemed to think better of it and permitted the mongrel to remain as one of the family, though clearly in disfavor.

The strongest and most courageous of all 
the litter was he with the hairs upon the face, who seemed to be the old wolf's favorite. When they were fed, he it was who always got the lion's share. The old wolf also permitted him to go farther from the den than any of the others, because he felt at once that he was a promising whelp who could look after himself.

For an hour or two the pups went creeping about, tumbling into holes and then scrambling out again with considerable fright, and having all sorts of adventures which probably seemed very important to their young minds. Finally, of one accord, they all came running to the old wolf, and then went scurrying into the den. Again there had been no sound of command, yet perfect obedience.

After their frolic they were tired, and soon were curled up in a ball, sleeping. An hour later when he of the hairy face, whom we will call Hairface, awoke and 
crept to the entrance of the den, the old wolf had disappeared, and he did not return until evening.

That first day in the open proved to be the forerunner of daily excursions into a wonderful world, full of surprises and with many things of which to be afraid. Each day the old wolf took them farther from home, until in a month's time they were often a mile from the den.

At first the game which they hunted was very small. Stalking grasshoppers and crickets may seem not very exciting sport, but when the grasshopper is one's first kill, it may be different; at least the young wolves thought so. They would go creeping stealthily through the weeds and grasses until game was discovered, when they would rush in, and usually lose the grasshopper. Many failures soon taught them that it was better to go slowly even at the last and not rush until within striking 
distance. They tore open the ends of rotten logs and ate grubs, but this secret was taught them by the old wolf. He seemed never to take any pains to teach them, but when he did anything important, he usually waited until they had gathered about to watch.

Nearly all young animals are more or less imitative; they learn from observing their elders. This fact is taken advantage of by dog-trainers who often put an old dog into the field and let the puppies watch it hunt. It is also always desirable to have a few good old hounds in a pack, that the young ones may learn properly.

After the grasshopper hunting came some real adventures by moonlight, in search of field-mice. These shy little fellows would be running in their tunnels under the grass-roots, squeaking away and having the finest kind of times when the wolf whelps came forth on their quest. It was 
almost useless to seek them by daylight, for then they were quiet. At first the old wolf called the whelps to a runway which he located in the grass, and they smelled the scent, until they knew mice. Then all four sat down by the runway to wait, each as motionless as a statue.

Ten, fifteen, twenty minutes went by, and only the usual night sounds, like the sighing of the wind and the hooting of an owl, came to their straining ears. At last Hairface, who was the most keen of the pups, thought he heard a far-away squeak, though it was so slight that he could not be sure. In the excitement of the moment he moved ever so little, and cocked his head a little more on one side, that he might the better catch the sound. But the old hunter glared at him so fiercely when he stirred, that he was powerless to move from where he was, and thenceforward remained as motionless as a gray boulder 
might have been in his place. The sound that he thought he heard had been real, and soon slight little squeaks came to the ears of the waiting wolves from the runways under the grass.

Presently the old wolf discerned a slight motion in the grass near by, and his intense look showed the whelps from which way the game was coming. Nearer and nearer drew the small prey, occasionally uttering his tiny squeak. When just opposite the point where the grizzled hunter sat, the old wolf pounced upon the spot where the grass wriggled; by putting one paw down hard upon the runway in front of the mouse and the other behind, he held him fast. It was but the matter of a second to poke open the grass with his sharp nose, and crush the field-mouse with a bite. But the old wolf. did not eat the mouse. Instead, he gave it to his favorite, Hairface, while the other whelps looked on, licking their chops greedily. 
This may seem like very small quarry for wolves, and indeed it was, but it served two purposes. First, it taught them the exciting game of hunting; and, second, it never does in the wild to despise anything that is meat. Just such bits as these mice, or even grubs dug from old rotten logs, might some day stand between the whelps and starvation.

It was useless to watch this same runway at this spot any longer, so the old wolf led them to another runway, and the fun began again. This time they did not have to wait so long, for the moon was now bright, and the frolics of the mice were in full swing.

The next mouse was caught in just the same manner as the first, and this the old hunter gave to the whelp who most resembled him, whom we will call the Wolf; while the poor Mongrel, who was half dog in looks, had to wait until the last.

When each had been fed from the results 
of the hunt, all took their places as before by a new runway, and the old hunter signified to Hairface that he might make the kill this time. The favored whelp was all excitement and could hardly wait for his mouse to come along. When it did at last appear, he jumped too soon, and the mouse ran squeaking back along the tunnel. It was a case of being overanxious, the common fault of all young hunters; so Hairface was not to be blamed, although he felt quite ashamed. This failure spoiled the runway even more effectively than if the mouse had been killed, for he would go back along the path by which he had come and notify all his relatives of the danger. A new runway was therefore sought at some distance.

This time they had a long wait. When Hairface's mouse did at last appear, he waited until it was directly opposite him, then planted his paws upon it, and 
swooped it up into his mouth, grass and all, which feat seemed greatly to please the old wolf. They did not quit until each of the whelps had caught his mouse.

This moonlight mouse-hunting was really a sort of child-play for whelps destined to become mighty hunters among wild beasts, but here was the very best kind of practice, and here they learned nearly all the rules of the game; all, in fact, except courage. They learned patience, how to turn one's self into a bush or a boulder, not to be too eager, and to strike at the right moment. 
CHAPTER IV

\section{THE KILLERS}




\section{CHAPTER IV}

THE KILLERS

The Scriptures tell us that the wild beast seeks his prey from God, meaning that through a God-given instinct he kills whenever he is hungry. In the same way it may be said that man seeks his meat from God, for he kills no less freely than do the wild beasts.

As cruel as the sea is the law of subsistence, whereby the things God has made of necessity war constantly upon one another. It is almost heart-breaking, when we stop to consider, that the dainty bunny, with his twitching nose, and his wig-wagging ears, at once so gentle and so shy, should be brought into the world, that half a score of beasts and birds, each less attractive and less lovable than himself, may sustain life. 
Yet this is the case, for wherever you find the trail of the rabbit, it is a trail of blood.

Mice, too, inoffensive little field and wood-mice, beautifully fashioned and interesting in all their ways, cannot even play in their runways under the grass-roots on a moonlight night without occasionally yielding up their lives.

So if the old gray wolf and his three hungry whelps sought their meat wherever they could find it, and killed savagely, they were but wild beasts obeying a God-given instinct and fighting the battle of life in an altogether creditable manner.

To be a poor hunter, and to miss where one tries to kill, is a much greater crime in wolf law than to kill an animal that one cannot wholly eat; for on the morrow the hunting may be poor, and then the left-over bits will prove most acceptable.

The old wolf, of course, had no theories about these things, and he broke the back 
of a fox or a rabbit with as little compunction as he would have chewed a straw. In fact, he enjoyed it, for he was a killer. The sound of crunching bones between his teeth was sweet music to his ears and warm blood tickled his palate as did no other fluid.

The moonlight hunt for meadow-mice was merely the beginning. Here it was that the young wolves took their first lesson, but they soon tried larger game. It took the wolf two or three days to secure the object lesson that he wanted next; but, as he was a patient hunter, he at last succeeded. Poor Mr. Woodchuck came to the den of the wolves, kicking in the jaws of the old hunter, for he had not killed him, but merely caught him alive that he might let the whelps worry him to death.

When the old wolf freed him near the mouth of the den, he backed up to the 
boulder, and stood on his hind legs, a sorry little figure, fighting for his life against great odds, yet game to the end. Hairface was the first to rush in upon him and he got a savage slash in the face, which caused him to draw back and look with astonishment at the woodchuck. Mice had never behaved in this manner. Before, the battle had been entirely one-sided. Now the question of courage came in. This was just what the old wolf had looked for. His whelps could not always kill mice. They would never be wolves if they did. They must learn to punish and to be punished, and to fight the battle to kill.

The Wolf next tried his luck with the woodchuck, and got a bad bite in the leg, which made him hold up his paw and look mournfully at it. All this time their sire sat on his haunches looking on gravely; but at this point, getting out of patience with the slow way in which the battle 
was going, he reached over and caught the valiant woodchuck by the scruff of the neck and whirled him over on his back. The whelps rushed in and each got a hold, but could simply kill him by inches. Little by little the fighting waned, as the valiant old woodchuck's strength gave out, until at last he no longer struggled. When all was over, it was Hairface who had the death grip. He had learned the trick; in after years he was always first to get this grip, and none were so quick or so strong as to overcome him.

Having learned woodchuck, the old wolf now took the whelps woodchuck hunting, and the first morning they had great luck. They surprised old Mother Woodchuck and the whole family feeding, and there was a lively scramble for the hole. Two of the young woodchucks went the way of their sire, Hairface killing one, and the old wolf the other. 
This was nothing, however, to the excitement that they felt when the old wolf would post the three whelps on one side of a cover, where they lay as quietly as three gray logs, while he beat the bush for them, driving whatever there might be of game into the ambush. The old wolf would quarter back and forth like a pointer, and nothing escaped his good nose and keen vision.

Often their prey got away, for the whelps were not experienced hunters, and it really needed two old wolves to play this game well; - one to beat the bush, and the other to make the kill when once the quarry was put up.

Their deadly work was done quietly and with dispatch. There was little snapping or snarling, once their puppyhood worrying habit had worn off. Only the Mongrel persisted in growling and barking, which greatly annoyed the old wolf, who saw in 
it a sign of weakness. His motto was, "Act, and say nothing."

Upon a sandy side-hill half a mile from the wolf-den, overlooking a snug little valley, was another family as interesting as the wolves; in fact, they resembled the wolves in many ways. The family in question was a litter of foxes. They did not live in a den, but in a burrow. The burrow was in a sandy side-hill so that it would be dry. A fox likes to have his front door at a good altitude so that he may look off across the country when he comes forth in the morning.

This burrow ran zigzag back into the side-hill for fifteen or twenty feet, although it did not reach a depth of more than four or five feet; but if one had attempted to dig out this family he would have found-it an all-day job. The quickest way to dig out a litter of foxes is to get the direction of the burrow with a pole, and then sink a 
hole eight or ten feet from the mouth, until you meet the burrow. From this point you can again get the direction of the underground passage, and sink another well still farther on. In this way, by sinking three or four wells, you can find the nest at the end of the burrow without uncovering the whole of the passage.

The foxes had been brought forth from their den at a certain age, just as the wolves had been, and introduced to the outside world. Like the young wolves, they learned grasshopper hunting, and thought it great sport. They were also initiated into the mysteries of mice-hunting, but for them mice would always be a staple, so it was not mere play in their case.

One day, about the first of September, the old mother fox took her litter of four promising whelps down to a narrow strip of cover, which was fringed with ripening blackberries. She had discovered that this 
was the favorite feeding-ground of a bevy of spruce partridges, who usually came into this cover in the late afternoon. The old fox wished to have the whelps trail the partridges and perhaps get a young bird or two. When half-grown, they will often squat and let a fox come up within springing distance.

The fox family had just entered this cover, and were busy looking for signs of the partridges, when the wolf family appeared. The old hunter posted his three half-grown whelps on one side of the cover, while he himself began beating the bush. He had not gone far when he struck the fresh trail of the fox family, and his good nose at once told him what was afoot. At the thought of the three waiting hunters outside the bush, his eyes glittered phosphorescently, and he began beating the cover diligently, though with care that nothing should escape the way that he had just 
come. But if the wolf had a keen nose, the old fox had an equally good one, and as the hunter made considerable noise, she soon scented danger.

She hastened to slip her family out at the other side of the cover and so to make their escape; but, instead ran them immediately into the way of the three waiting wolf whelps. Then there was a scurry and a scuffle that was anything but play. Lithe red forms flashed in and out of the bushes, closely followed by larger gray ones. There was twisting and turning, dodging and doubling, and then at last came the death struggles.

Hairface singled out one of the foxes for his own and went after it like the wind. Again and again he was almost successful, but by a sharp twist in the trail, his victim would elude him. At last he was fairly alongside and his strong jaws closed upon the fox just behind the shoulder; with a 
sharp bite and a jerk, he broke young Reynard's back and stretched him upon the ground.

When this little flurry in the cover had ceased, it was seen that the wolves had bagged two of the young foxes and the dam herself, the old wolf having run her down and killed her while the whelps were pursuing the young foxes. Of the family of five, who themselves had been looking with bloodthirsty appetites for the partridge family of ten, only two now remained, and they were so badly frightened that they left that part of the country, and never came back. Thus it ever was and ever will be. The big game continually eat the smaller.

Over two ranges of hills and across two streams to the northward, living partly upon the streams, where lily-pads were plenty, and partly in the wooded hills, where they could escape the flies in the hot 
weather, there dwelt a doe and a little dappled fawn.

They killed nothing that crawled, ran, or flew, yet themselves were in constant danger. The lynx viewed them from the thicket with greedy eyes; the bear licked his chops hungrily whenever he caught sight of them ; and the wolves warred constantly upon the deer family, and were their most deadly foe. Even the great bald eagle, sweeping in majestic circles far up in the peaceful blue heavens, had once seen and swooped for the fawn; but some instinct had warned the doe of peril, and she had hurried her charge into thick cover just in time to escape the cruel talons. This was when the fawn was but a few days old; now he was a sleek little fellow of five or six months, who could nibble at the grass-heads as busily, if not as effectively, as his mother.

In an evil hour for them the two crossed the streams and the rugged hills that lay 
between them and the range of the wolves, and came over into the country of the gray hunters. The old wolf discovered their presence almost the day of their arrival, and took the whelps out, that they might learn the scent of deer. He did not strike at once, for it was good practice for the whelps to trail the doe and the fawn, observing their ways and getting used to the deer family, who would always be important in their after-lives.

If they had shown any signs of uneasiness, or of quitting the country, the old hunter would have given the word; but he felt quite safe and could afford to abide his time. One morning early in October, when the air was keener than it had yet been and the frost along the watercourses was heavy, the wolf pack broke their fast on venison.

There was something about this keen autumn air that gave a new zest to the appetite. The whelps were all excitement 
as the old wolf led the way down to a clump of spruces where the doe and the fawn usually spent the night. They seemed to read his thought, and to know without being told what was afoot.

Even Mr. Burroughs, guarded as he is in admitting intelligence in the brute creation, says that birds and animals appear to have a mode of communication which we do not understand, and which he thinks may possibly be telepathy.

The old wolf stationed his companions about the thicket, while he went inside to start out the deer family. They did not need any special frightening, for the sight of him was enough to drive the doe, with her helpless fawn, frantic; a deer becomes frenzied and loses its head sooner than almost any other of the wild creatures. But there was another cause for the doe's fear, for something told her that the truce between her and the wolves was over. 
It was not the grizzled veteran's plan to kill the fawn himself; for what was the killing of one fawn to him, when he had killed scores? He would give the whelps the first chance, and, if they failed, would come in as a reserve. So, by a clever dash at the two, he separated the fawn from its mother, and then drove her at a breakneck pace in an opposite direction.

The three young hunters took their cue immediately and went after the fawn. This was new game for them, and they did not understand reaching for the throat grip, but contented themselves with snapping at his legs. Up and down the terrified little deer raced, bleating pitifully and seeking to elude his pursuers.

Finally, Hairface caught him fairly by the hind leg and brought him to earth, and the Wolf and the Mongrel both pounced upon him. When the old wolf returned from running the doe out of the country, the 
fawn was dead, and the three bloodthirsty hunters were gorging themselves just as any hungry beasts might be expected to do. Does it seem cruel to you that the dainty little fawn, who had never done anything worse than to nibble grass-heads and suck his mother's udders, should be pulled down to glut the appetite of wilderness dogs? At first thought, perhaps it does; but let us look at it from the wolf standpoint.

The whelps were lank and needed meat to fill them out and to give them strength for the coming winter. They had not killed for sport as man might have done, but for meat. They did not kill more than they wanted for their immediate hunger, and they killed quickly and humanely. This, too, was the way of their kind; what wolves had done from the days of the first wolf. Venison was to them legitimate meat; meat that could be had for the taking; meat that belonged to them, just as the creatures 
of the wild belong to any good hunter, be he two-legged or four-legged.

Is it not better to kill a deer because one is hungry, than for the mere pleasure of mounting its head and satisfying one's self as to how it looks? If we condemn the wolves for seeking their meat from God, what shall we say of the hunters who have devastated the great plains and robbed the forest of its first denizens, merely for sport? 
CHAPTER V GOOD HUNTING 


\section{CHAPTER V \\ GOOD HUNTING}

As early as possible in the course of their education, the old wolf introduced the whelps to that most dreaded of all scents, the man scent. It was not every day, however, that man penetrated to these remote regions and the opportunity did not offer itself until a Canuck wood-chopper came into the wild to cut his winter supply. $\mathrm{He}$ did not approach very near to the den among the rocks, but the wolf family had by this time extended their operations for miles in every direction. Distance was nothing to these tall, gaunt, galloping wilderness dogs.

The wood-chopper, Alec Roberts by name, came into the forest each year and builded himself a shack while he was en- 
gaged in his work. $\mathrm{He}$ did this in the early fall, but did not draw the wood until snow came.

For several days the wolf family slunk about where Alec labored, watching him, but taking good care that he did not see them. To the whelps he seemed not as much a menace as to the old leader, who had felt man's power too often to doubt it. It is probable, too, that the puppies also inherited from their mother a natural liking for man, and so were inclined to be friendly. The old wolf, by his actions, said: "This is a terrible enemy, more to be feared than all others;" but their natural instincts said: "He is not our enemy. We have known him somewhere before."

So much was this the case that, when they one night discovered the wood-chopper's coat, which he had left upon a woodpile, and the old wolf took the cubs to smell the garment of this dreadful man 
creature, the Mongrel did not even bristle with fear when he sniffed the coat, but actually wagged his tail. This so exasperated the old fury that he fell upon the whelp and nearly throttled him in his anger.

The thing about the wood-chopper that most interested and puzzled the wolf family was his wood-cutting. They would sit in the shadows, watching for an hour at a time while the creature, who had such wonderful powers, stood upon his hind legs,-in fact, that was the only way that he ever stood,-and whacked away upon the tree against which he seemed to have a great spite. Finally, as the tree began to sway, they would get uneasy, and when at last it fell with a rush of wind and a thunderous sound that shook the forest, all would slink away. It was usually several minutes before they could again get up courage to watch one who could bring down the mighty trees with such force. 
The wood-chopper not only cut wood during the four or five weeks spent in the forest, but he also trapped along several small streams, that threaded their way through the low ranges of hills with which the country was broken.

These traps were set for otter, mink, muskrat, fishers, or almost any of the furbearing animals that were stupid enough to get into them. Alec had brought a few small steel-traps with him for this purpose; he also made several dead-falls by driving stakes about in a circle and leaving one side open and suspending a log above this open spot. The log was held up by a figure four, the bait being attached to the trigger. This is the most common home-made trap used in the northern woods by the halfbreed trappers.

As soon as Alec had his traps all set, the old wolf with the whelps visited each, either springing it or in some other way 
rendering it unserviceable. They never ate any of the bait, but preferred to kill their own game; the old hunter's idea being that poison did not get into meat that they killed themselves.

For nearly a week they lingered about the wood-cutter, spoiling his traps and becoming acquainted with his manner of life, but there was always a difference of mind between the old wolf and his whelps. To him, the man was deadly, wholly without mercy or consideration other than hate. To the whelps, he was partly a friend, partly an object of curiosity.

The old wolf noted these things and they filled him with forebodings. He had never known wolf whelps to act like this before. Finally, they tired of watching the woodcutter, and went back to their old range.

It was a wonderful morning for the whelps when they came forth from the den and found the ground white with snow. 
At first they went about, holding up their paws and looking inquiringly at the old wolf; but seeing that he paid no attention to the strange new whiteness, which now covered all the earth, they ceased to notice it, and soon got used to the cold.

There was another curious thing about this new substance. Wherever they went, they left tracks. The whelps had seen these before in the mud; but now the marks were all around. They not only left tracks themselves, but the rabbit and the partridge did so too, and it was easier to follow them now than it had been before. When the ground was bare, they had to follow slowly, and if the trail was old they could not do it at all. Now they could follow rapidly, and at sight if they wanted, although it was not always safe to trust too much to one's eyes. It was better to depend upon both sight and scent. 


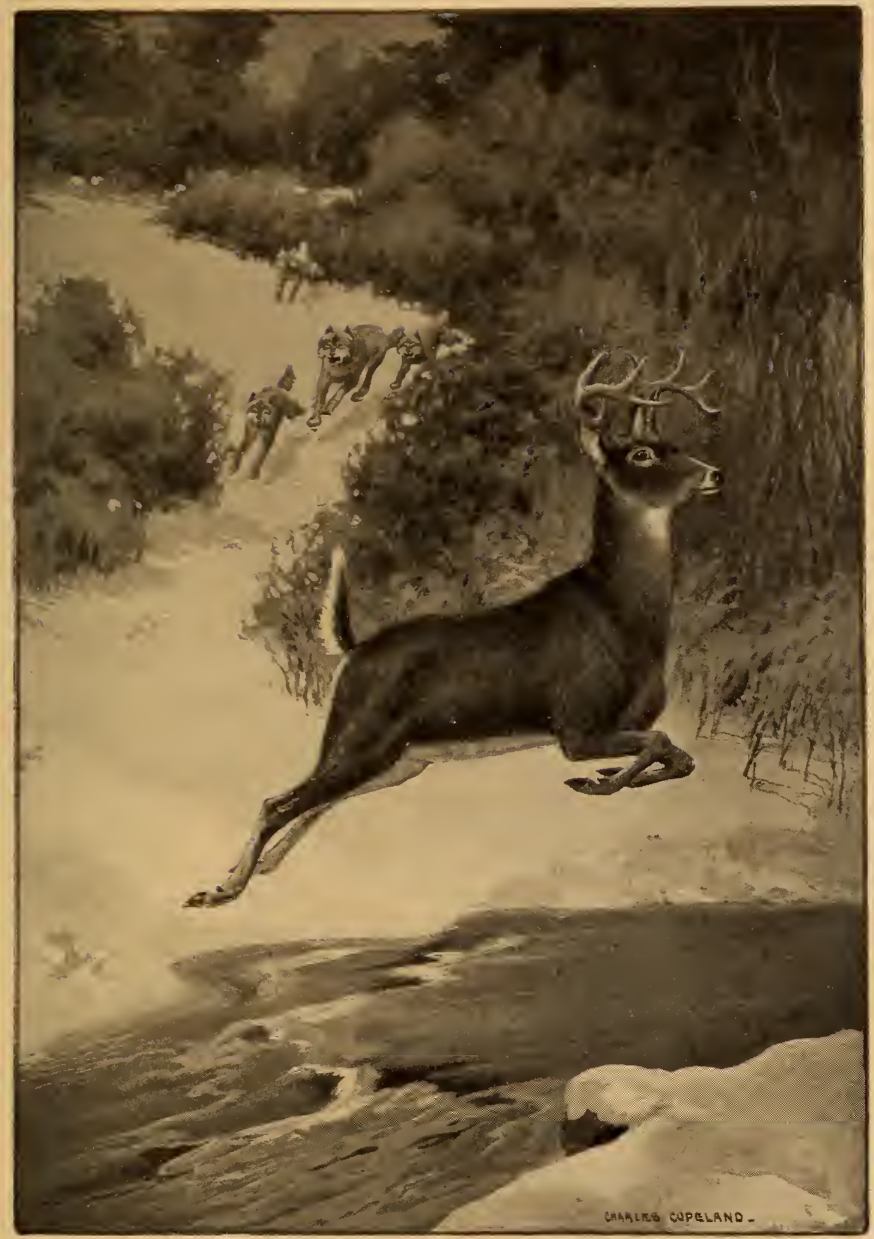

They Started a Fine Buck Out of a Clump of Spruces 

They had the greatest kind of fun rabbithunting. They would pick up a fresh track and, spreading out a little, that they might recover it easily when the rabbit doubled, would follow him pell-mell to the end of the trail. If the rabbit did not hole, they would usually catch him in half an hour, for the poor little thing could not run with these tall galloping dogs.

But even this rabbit-hunting was tame compared with the deer-hunts in which they participated on several occasions.

One morning near the middle of November, when there were about six inches of snow upon the ground, they started a fine buck out of a clump of spruces where he had been spending the night. The wind was in their favor or they never would have got close to him before he took alarm. Away he went, clearing the low bushes with great bounds, and rising into the air at any obstruction as lightly as though the laws of 
gravity were nothing to him and running was his greatest delight.

He was so fleet and so soon out of sight that it would seem almost like folly to pursue him, but the grizzled old hunter knew better and he led the pack after him at a steady long lope.

It was a fine day for a run. The autumn sky was absolutely without a cloud, and the air was as clear as crystal. In the east the sunbeams were falling across the sprucetops and painting the sky above the forest horizon-line with pink and saffron. The new snow was a spotless white, which only served to make the dark blue-green of the larches and spruces more dark and lustrous.

At first Hairface, who was much the swiftest of the whelps, was inclined to race with all his might after the buck; but the old hunter called him in with a savage snarl. He knew well that this race was not to the swift, but to him of endurance, and 
that to wind one's self in the first half-hour would be utter folly; so he made the whelps keep the long even lope that he set.

The country was very rough, and as the race grew hotter and hotter, the buck took pains that the trail should be a hard one to follow. He plunged into deep swamps, where there was a perfect tangle of laurel and small evergreens. He took frightful jumps from high bluffs, while the wolf pack were obliged to go around. He leaped broad streams and always gained time by this as the wolf rather hates a wetting. For several rods he ran upon a series of ledges where the snow had been blown off, and here the pack had to circle entirely around the ledge to find where he left it. But all this was good practice for the whelps. They saw how the old wolf quartered to pick up the trail and soon Hairface was imitating his sire, though of course without his fine 
judgment. The old wolf had an instinct that usually told him where they would find the trail, once they lost it.

At first, the trail had led in and out about the region where the buck had been started, not going over two or three miles away; but, after about an hour, the buck became thoroughly frightened and led them straight across country, not stopping now for any antics. He at last appreciated his desperate plight.

A fine figure was he, as he raced through deep gulches and over high bluffs, spurning Mother Earth as though his small legs had been so many steel springs. His head was up, his eyes were wide with fear, his flanks were covered with sweat, and foam dripped from his muzzle. His cord-like muscles worked under his loose hide as freely as though the whole fine mechanism had been thoroughly oiled for the race that very morning. Last, but not least, his 
white flag was up, and it jerked nervously as he made his great leaps.

No matter how fast he ran, or with what gigantic jumps he cleared the thickets, that steadily-running gray pack was always just about so far behind. They did not spurt and try to catch him in a race for the swift, for that was not their game. It was a race of endurance. Generations of wolf sires had handed down the knowledge that a wolf cannot often catch a deer in a mad flight across country, but he can wear him out with his persistent gallop. True, their tongues were out, and they panted freely, but this did them no harm; it was the natural way to breathe during a long run.

The worst mistake that the buck made was to drink too freely from the streams whenever opportunity offered. This filled him up and helped to make him loggy, for in such a race as this every pound tells.

At last the gray hunters drew in sight of 
their quarry, and then the whelps wanted to race after him with might and main, but the old hunter forbade it. No one could tell how many more good miles the buck was capable of. To frighten him badly might defeat their purpose.

Instead of racing, they trotted after him like collie dogs ; but they always took pains to keep him going at a good pace. There must be no stopping in this contest; no minutes in which to catch breath. It was the steady, unremitting strain that would tell; so they gave him no quarter and the race sped on.

The sun reached high noon and there was no slacking; it dipped toward the western hills, and blue shadows stole across the snow, but still pursued and pursuers kept at their life-and-death game.

By four o'clock, the wolves had come up to within three or four rods of the buck, who was badly spent. His breath whistled 
through his nose in gasps, and he was reeking with sweat. His eyes were wide with terror and he looked continually back at his pursuers. Once he stopped as though to give battle, but a snarl from the old wolf sent him about face and lent new speed to his flagging limbs.

Presently they came out on a meadow where there was a small lake, of two or three acres in extent, fringed with bushes. It was toward this trap that the old hunter had been heading the buck for the past hour. Twice he had turned him this way.

Still gasping for breath, straining every nerve to escape and without waiting to consider the probable consequences, the poor fugitive plunged into the icy water and struck out for the opposite bank. Here was his great mistake, for, had he kept to the woods, he might possibly have lost his pursuers under the friendly mantle of the impending night. It is much harder to swim 
than to run, especially when already winded, and he had barely strength enough left to draw himself up on the other side.

As soon as he sprang into the lake, the plan of the old hunter was apparent. $\mathrm{He}$ left two of the whelps to guard the shore where the buck had taken to the water, and he and Hairface quickly slipped about the end of the lake to the farther side. When the buck, dripping and exhausted, spent from his long swim, scrambled out on the bank, blowing and trembling, they sprang upon him.

The old warrior got the throat grip at the first snap and Hairface caught him by the gambrel joint. Together they brought him to earth like a log. Although he struck out viciously with his sharp-cutting hoofs, and made the best fight that he could in his weakened condition, it was hopeless. A minute later the old wolf sent the cry of the kill echoing across the lake, and the Wolf 
and the Mongrel came galloping around to the feast.

The slaying of this fine buck, however, was but child's play compared with the pulling down of a great bull moose, which the pack accomplished later on in the winter. But this was in the deep of the snow, when other game had become scarce, else the old wolf would not have counseled so hazardous an undertaking, fortified as he was with merely three half-grown whelps.

As the days shortened in December and the month drew near to its close, the snows became heavier and heavier, until the laurel in the rabbit-swamps was entirely covered, and the little scrub spruces and hemlocks were merely white mounds. So changed was all the landscape that one could hardly have recognized familiar scenes.

In some places the wind played fantastic tricks with the new snows. Here, it would pile them up mountain high; there, upon 
a hilltop, it would sweep the earth almost bare, so that the brown fronds and the tops of the weeds would show. All of the lower branches of the evergreens were weighed down with snow and in many places one could walk up into a tree several feet from the ground. Such were the pranks of the wind.

In a season like this the rabbits, squirrels, spruce partridges, and all other creatures who were meat for the wolf pack, stayed indoors as much as possible. What was the sense of going abroad when all the sources of food were buried so deeply under the snow? Perhaps one might be hungry, but one would get still more so by floundering about in a hopeless quest for food; food which was not to be had just then at any price.

So it happened that, although the pack scoured the rabbit-swamps persistently, and nosed about the roots of trees where a prov- 
ident squirrel might be routed out, or even dug under the snow for mice, frequently they went supperless to bed.

Perhaps you may wonder where their beds were when the snow was several feet deep. In this heavily timbered northland, there are places where the spruces stand so thick and their boughs so intertwine that onc can hardly make his way through them even in summer-time. Here in New England, I have often seen such sheltered nooks where, under a clump of thickly interlaced spruces, not a flake of snow would fall all winter long, and the dead needles would be almost as dry in the spring as they were in the hottest days of August. In fact, the snow does not penetrate to these spots nearly as freely as do the drenching rains of summer. Reynard, the red fox, in winter often prefers these sheltered beds under the spruces to his den, and in such places the wolf family made their winter home. 
It came about that, when the snows were piled five or six feet deep on the level, and in many places ten or twelve feet where it had drifted, when the winds bit like a serpent, and the steely bright stars in heaven were cold and pitiless, starvation, that other wolf, grim and terrible, stared the pack in the face. This gray, slinking figure was as persistent in his hunting of the pack, as they had been in hunting the denizens of the forest. It followed them by day and night. Even in their sleep it came and stood over them.

So much did this creature of their fancies, who was a terrifying reality, prey upon them, that they became gaunt, evil-eyed and quarrelsome even among themselves, where good feeling usually reigned.

It was not until their plight grew desperate that the old hunter gave the word that they should undertake the dangerous feat of killing a moose. 
A few days before, the sire had left the whelps behind and gone twenty miles to the north ward to reconnoitre in some moose country of which he knew. There was no need of wearing out the strength of the entire pack in this scouting, so he went alone, and the whelps spent the time while he was away in futile hunting or lying quietly under the spruces.

The old wolf found two moose-yards, one of which contained two bulls, three cows, some yearlings and a couple of calves. He spent nearly half a day in trying to cut out one of the calves from the herd, but this herd was wonderfully well protected by the bulls who kept them bunched and were proof against all the wiles of the wolf.

The other yard was nearer home, and contained a solitary bull, a well-grown fouryear-old, who had concluded to yard by himself that year. It was useless to think of 
overcoming him alone, so the wolf went back for his rather feeble pack.

Moose of the size and strength of this bull frequently stand off a pack of six or eight full-grown wolves, and here the old hunter was advancing to the attack with but three half-grown whelps. Clearly it was a case where brains must win, if they won at all. This was just where the experienced leader was strong. He could fight with his wolf cunning as well as with his terrible fangs. Like the hunting of the buck, this would not be a race to the swift; it would be a case of endurance; of steady, persistent harassing; of threat and of menace which would not cease until the bull had paid the price of being meat for the pack.

Such was the old wolf's plan as he advanced through the deep snows, with his three eager whelps, to the yard of the solitary moose.

Although rather young, the bull, upon 
whose destruction the wolf pack were intent, was a mighty beast, with a well-grown set of horns, and a deep and powerful chest. His coat was coarse and long, of a smoky gray appearance. His mane and the hair upon his bell were jet black, while the insides of his legs and his belly were tawny, almost yellow. So strong was he that he swung through the deep snow like a mighty snow-plow, and he bent down small saplings, on which to feed, with the strength of a Goliath.

His yard was well trodden, for it was not large, so there was no chance of getting him into the deep snow; crusting him, as a woodsman would say. The wolf pack, therefore, under the lead of the old hunter, began a persistent hounding and harassing of the moose. Sometimes they would merely sit about him upon their tails looking at him, a grim expectant circle. Even when they made no sound, this worried the bull, 
and he would constantly turn his head trying vainly to watch them all at once. If this annoyance seemed not to be enough, the whelps would bark intermittently at him, which always drove him into a rage.

The old wolf himself never barked; but the whelps, being half dog, barked often when excited. Then the bull would charge furiously, first at one and then at another. But as often as he charged in this reckless manner, he would discover that terrible teeth were clicking at his heels like a great steel-trap, and he at once understood the danger of being ham-strung. He tried never to allow the old wolf to get in his rear, for he might render him helpless at a single bite if he found just the right spot. So the bull soon resorted to the stratagem of backing up to some thick cover that should protect his rear, and keep all his enemies in his front, where he could guard himself with lowered horns and sharp-cutting hoofs. 
They were not much worse than flies; a constant annoyance, but in their present temper not to be feared. They would soon tire of this useless teasing. Instead, however, they kept it up all through the day, and, when the blue shadows of night came creeping across the snow, showed no signs of quitting.

The moon, luminous and large, climbed over the eastern hills, and the myriad glittering spear-points of the stars pricked through the cold gray heavens. Still the four gray shapes stuck to him like burrs. All through the night, the hoarse, intermittent barking of these wolf-dogs punctuated the mournful shrieking of the wind in the tree-tops. The complaining of the winds, the hooting of a great horned owl, the sharp cracking of a tree as the frost broke its heart, and the hoarse barking of these death-watchers made a solemn and terrible night chorus. 
When the delicate pink and bright red of the morning streamed up the eastern horizon, and the pale rays of the sun fell across the spruce-tops, they were still playing their game of endurance.

That forenoon the old hunter left the whelps to keep up the worrying process while he went to hunt food for the pack, for they were nearly famished, and the tactics which they were following were telling on them as well as on the bull. About noon he brought back a rabbit, and, although it was merely a taste for the four hungry dogs, it put new life into them, and the worrying of the bull was renewed with zest.

They now drew in much nearer than they had dared to the first day. His fear of them was not getting less; in fact, it hourly grew. Perhaps he foresaw with prophetic vision the coming death struggle. The method of the pack was not to flee 
pell-mell when he charged, but merely to slip from his reach, just as a collie dog does before cattle. He never runs away but simply slips a yard to the right or the left, avoiding the horns by so small a margin that you shudder for your pet. This tantalizes the charging cow, and does not waste the strength of the dog.

When, for the second time, the blue shadows lengthened along the snow, the death-watch had drawn in to within fifteen or twenty feet of the bull, who stood with lowered head and bloodshot eyes, watching the wolves narrowly. He was wrought up to the highest pitch. His eyes flamed, his breath whistled through his nostrils, and his bell and mane were covered with frost.

That night there was not so much barking, but the ghastly circle drew in still closer; so close, in fact, that the old wolf occasionally sprang in and made a vicious snap at the bull's hind quarters in hopes 
of ham-stringing him. This kept the moose constantly on guard. If he dared to doze for even a second these terrible jaws were clicking at his great sinews. One slash rightly directed there would render him helpless. Well he knew this, and, although his head was so heavy that it seemed to weigh a ton, he braced himself and glared straight at his relentless enemies as he would at a rival bull that he expected to charge the next minute.

If they only would charge, he would feel better. His mighty antlers and his sharp hoofs would soon scatter them. He would break their backs, and either toss them high in air, or crush them to jelly in the new snow. But they would not fight fair. They were killing him by inches, like the water which wears away the stone, a grain at a time.

There was no hunting for the pack the third day, but a constant narrowing of the 
circle, and a constant menace of snapping jaws and advancing fangs.

That night, when the pitiless stars looked down, when the demoniacal winds shrieked in the tree-tops and the shimmering light was cold as death, when far down in the frozen earth the pulses of life slept, at an appropriate death-hour, the old wolf and his three eager whelps grappled with the mighty bull in the final battle. $\mathrm{He}$ seemed so exhausted and they were so famished, the gray wolf of hunger pressed them so hard, that they chose the lesser of two evils and welcomed the desperate struggle, which could be no longer delayed.

Like a wave of fury they broke upon him, springing and snapping, advancing and retreating before those death-dealing antlers and crushing hoofs. For ten minutes there was obstinate fighting, and the air was filled with the sounds of the combat. There were snarls and hoarse barks from 
the pack and the whistling breath of the forest monarch, together with deep grunts, and the mighty thud of his hoofs as he dealt sledge-hammer blows at his illusive adversaries.

At last Hairface, who was more courageous than prudent, caught the great blowing fury by his long fleshy upper lip; his dog tendency caused him to hold on, and this was almost his undoing. A wolf leaps and snaps, leaving a frightful gash and then leaps again. These should have been Hairface's tactics, but instead he held on.

The raging bull reared in air, carrying his plucky adversary with him, but when his sharp-cutting hoofs descended, one of Hairface's hind legs hung limp and useless and one of his ribs was broken. Another blow such as this would finish him. Seeing the imminent danger of his favorite whelp, the old wolf sprang in recklessly, and the 
Mongrel and the Wolf followed his example.

They tore at the monarch's legs and gashed him in a score of places. $\mathrm{He}$ caught the Wolf upon his antlers and tossed him high in air, to fall like a log. $\mathrm{He}$ struck with his hoofs like a batteringram. There were no more feints now. It was a question of whether they could pull him down before he killed the better part of the pack.

In a lucky moment for them, the old wolf ham-strung the desperately-fighting moose, and his hind quarters sank to earth, helpless. Still standing for a moment upon his fore-legs, he ripped from right to left with his antlers and then toppled over. They were upon him like a submerging wave.

In three minutes more it was all over. The great moose had forfeited his life and was meat for the pack; but they had not gained 
their object without cost. Hairface could barely drag himself about, while the Wolf had bought his share of the meat with the price of his life, for he was already stiff upon the snow.

What a gorge it was that the moon and the stars looked down upon when the famished pack ate their fill! 
CHAPTER VI

IN THE TOILS OF MAN 


\section{CHAPTER VI}

IN THE TOILS OF MAN

Winter, with its deep snow and biting frost, its loneliness and deprivation, came and went, and all the countless trees on the hillsides and in the deep valleys again shook out their green banners with the approach of spring. Again the arbutus shed its illusive fragrance in the pasturelands, the dog-tooth violet gemmed the brook-side, and all the myriad nameless voices of nature were heard in the land. With a glad rush, life came flowing back into every stem and stalk, and again the green earth was glad. Little by little, so gradually that you could not have told where one left off and the other began, spring merged into summer, and the old world rioted in color and fragrance. Just 
as gradually as it came, the summer waned, and the scarlet and golden streamers of autumn danced in the merry breezes, the first bright camp-fires of the dying year.

Hairface was now a year and a half old, and, with the exception of the long coarse hairs upon his face, was a perfect wolf. His high forehead and massive jaws, his well-developed shoulders and bushy tail, all proclaimed him a wolf. His nature and habits of life were also those of the wolf. He slunk through the cover like a gray shadow; he crept upon his prey as noiselessly as the death he personified; and he struck like lightning.

Even his sire, the old grizzled veteran, was not a more skilful hunter than he, for he combined with the wolf's quickness of motion and keenness of scent the intelligence of the dog. He used his head in his hunting even more often than did his sire. This was where the deerhound blood told; 
otherwise the dog traits were entirely lacking. Of affection, he did not even know the meaning. The old wolf he feared, and the Mongrel he despised; but he would not much longer fear his sire, for even now he rebelled when chastised, and they had barely missed coming to a desperate struggle on more than one occasion. It was only because the old wolf rather liked Hairface that he forebore giving him the thrashing that he sometimes merited.

In the second autumn of their whelphood, the old wolf shifted their base of operations from the wilderness regions and came in closer to the settlements. Somewhere in the dim vistas of his memory there were tantalizing pictures of good hunting near the home of man. Particularly were these scenes connected with some woolly white animals that were to be found in large flocks, and belonged to their worst enemy, man. These were stupid creatures, much easier 
than a deer to run down and kill, and their taste was delicious even to memory.

Just about this time the good people, Scotch and French, in the little parish of St. Boniface, began to hear alarming stories of three great wolves that were ranging the country, killing sheep, and on one occasion even pulling down a yearling heifer.

Rumor, which always runs riot in such out-of-the-way places, had it that they were much taller and larger than ordinarily. As wolves had been very scarce in the region for several years, at first the inhabitants of St. Boniface were inclined to think that some large dogs had turned sheepkillers and had been mistaken for their more ferocious cousins.

Finally Roderick McElwain, our friend of the tote-team, saw the small pack. It followed him one moonlight evening for several miles, as he was on his way home from a husking party in a distant parish. 
Roderick knew wolves as did no one else in the village; he had encountered them while driving the tote-team from McGregor's Point to the lumbering-camps on the upper Ottawa. So when he pronounced the pack to be composed of three mighty wolves, there was no longer any doubt about it.

This statement, from so trustworthy a source, made a great stir in the parish. It would never do to allow such a pack to range the country; it would not be safe for either man or beast. Accordingly, a great hunt was planned, which should destroy these freebooters, who took such heavy toll of the farmers.

About a score of men and boys assembled on the appointed day. They were armed with every conceivable kind of weapon, and the pack of dogs that accompanied them was composed of about every breed ever seen in Canada. Two full-blooded fox- 
hounds were depended on to do the trailing, and the rest of the pack was to furnish the moral support, with two Great Danes to do the actual fighting, when they should come up with the wolves.

Within two or three hours, the better part of the pack had given up in disgust; but the hounds still trailed the wolves, with the Danes in the distance. Toward night one of the big dogs came limping back to the village, horribly bitten; but his mate and the two hounds were missing. A few days later they were found in the woods by some wood-choppers, each with his throat torn open.

This put an end to the wolf-hunting, so the pack went unpunished as far as the settlement was concerned, although several old hunters kept guns loaded for them, and Roderick himself took up the matter of ridding the country of this new menace.

His first experiment was to purchase 
about a score of powerful traps, which he set wherever he heard of depredations by the wolves; but, as this pack never ate anything that they did not kill themselves, the baits had no attraction for them. Besides, the old wolf had had some experience with steel-traps when he was younger, and could scent one almost as far as he could mutton; so nothing came of the traps but vexation.

Roderick next tried poison. Whenever he heard of a killing by the wolves, where they had left a partly-eaten carcass, he at once visited the spot and made several slits in the meat, inserting strychnine; he also cut off small pieces and treated them in the same way. All of this work was done in the most scientific manner. None of the meat was touched with the bare hand, and care was taken to leave as little scent as possible. It was all for naught, however, as far as the wolves were con- 
cerned. The old hunter's nose was never at fault.

Two or three of the young men of the settlement, under Roderick's lead, then tried to shoot the wolves by waiting for them on moonlight nights at a bait that they left as an allurement. It was the body of a dead horse, and near it the boys built a scaffold six or eight feet from the ground, from which point they watched their decoy. By this time the wolves were credited with unheard-of ferocity and cunning, and the boys did not dare wait for them upon the ground, lest they might be overpowered. But, like the steel-traps and the poison, this stratagem also failed.

When wolf-hunts, traps, poison, and guns had all proved useless, Roderick tried a new kind of trap which he had read of as being used successfully in the West. This was a pitfall about eight feet in depth, with perpendicular walls. It was made so 
deep and the walls were so steep, that a wolf, if once he stumbled into it, never could get out.

Across the middle of the mouth of this pitfall was placed a stick, which acted as an axis for a platform over the mouth of the hole. When everything was ready, the platform was covered with leaves and grass and made to look natural. Such a pitfall was usually baited by putting some kind of meat upon the platform, but Roderick placed his baits at a distance. His idea was that the wolves might be circling about the baits inspecting them, as he had discovered was their wont, and accidentally stumble into his trap.

Each morning he visited it, reconnoitering from a distance, as he did not care to leave any fresh scent in the vicinity.

For the first two mornings, nothing seemed to be disturbed; but on the third morning he saw that the platform was 
slightly tilted as though something had whirled it over.

$\mathrm{He}$ approached carefully, reinforced by two comrades, and peeped over the edge of the pitfall. At the bottom of the hole was a gigantic gray wolf. The animal was cowering upon the ground, for, although a terrible fighter, the wolf cowers easily when taken off his guard; this one seemed to be trying to slink into the very earth.

"We've got him," Roderick whispered eagerly to his companions.

The other boys were as much excited as he at this astounding news, and all drew close to the mouth of the pit to look down at the captive. Sure enough; there he was at the bottom, lying flat upon his belly, his yellow eyes gleaming fiercely up at them through the semi-darkness.

"What shall we do with him?" asked one of Roderick's companions.

"I know what I am going to do with 
him," replied the young Scotchman. $\mathrm{He}$ cocked his rifle and again peered down into the pit.

What a great beast he was, and what a menace there was in those two eyes that burned like coals with the hatred of the wild animal for man! Roderick shoved the muzzle of the rifle over the edge of the pit and lowered his cheek to the stock of the gun to take aim.

With a snarl that fairly made the youth's blood run cold, the cowering wolf leaped to his hind-legs, putting his fore-paws upon the sides of the pitfall and reaching his mighty jaws with their gleaming fangs almost up into Roderick's face.

With a cry of astonishment and fear, the young man sprang back, almost dropping the rifle in his haste; but he still gazed with riveted eyes into those of the great gray wolf.

It was the typical wolf head, with high, 
intelligent forehead, and long powerful jaws that could do such fearful execution; but the face was sprinkled with long, coarse, bristling hair, such as is often seen on some varieties of hounds.

"Boys," exclaimed Roderick, after a moment of intense silence, "that may be a wolf, but his face is that of Vixen, my old Irish deerhound. The expression is the same, and the long coarse hair is the same. No one ever saw such hair as that upon the face of a full-blooded wolf. I'd bet almost anything that this is one of her pups.

"I don't believe I ever told you, but she ran away and mated with a wolf, and I afterward accidentally shot her. I felt mighty cut up over it and so kept quiet; but they all know about it at the lumbercamps."

The longer Roderick gazed at the glaring visage of Hairface, the more certain he became that this fury now confronting 
him was one of the old deerhound's whelps, until at last it became an absolute conviction.

"Half of that wolf belongs to me by rights," he said finally, "and the other half I am going to appropriate. Boys, let's take him home alive."

But his companions laughed the proposal to scorn.

"Might as well think of taking home a streak of greased lightning," said Hugh Boyle. "He's all fight, from the tip of his nose to the end of his tail."

"I guess it will be a sorry day for us if we undertake to get him alive," remarked the second. "You had better shoot him before he chaws some of us up."

But Roderick was stubborn, as only a Scotchman can be, so of course the others had to give in.

Hugh went to the nearest farmhouse, which was nearly two miles away, for rope, 
and the other boys sat down by the pit to watch their captive. Seeing that there was to be no immediate hostility upon their part, Hairface at last lay down upon the bottom of the pit to await his fate.

When Hugh returned with about one hundred feet of half-inch rope, each of them secured a good club, four or five feet long, that they might stun the prisoner if it became necessary.

The rope was cut into two pieces and a slip-noose made at the end of each piece, Roderick's idea being to throw two nooses over the wolf's head at the same time and then to choke him into submission. A wolf, when once cowed, shows very little fight, although, up to the point where he is fairly beaten, he is most desperate.

When all was ready, Hugh took one improvised lasso and Roderick the other, and they lowered them into the pit in an attempt to snare their victim. He dodged 
and twisted from side to side, his great jaws clicking like a steel-trap, and more than once they were obliged to draw up the rope and make a new noose, the old one being so badly cut that it was no longer serviceable. But patience will accomplish almost anything, and Roderick persisted, although his companions again and again entreated him to shoot the wolf before he got loose, and did some of them harm.

At last he slipped his noose over the head of the frantic Hairface, who fairly went wild as the rope tightened upon his throat. He cowered in the bottom of the pit and sought to cut the cord ; but Roderick pulled upon it with all his might, bringing the wolf upon his hind legs, and in this position the other noose was easily slipped over his head.

Then, with a boy at the end of each rope, they slowly lifted the strangling wolf out of the pit, while the third boy stood by with his club in readiness to strike if necessary. 
Restraint of any kind was new to Hairface, and he struggled like the mad beast that he was. His tongue protruded from his throat its full length, his eyes started from their sockets, foam dripped from his powerful jaws, and hoarse snarls escaped from his throat.

He was fairly bursting with fury, yet terribly impotent. Never before had anything availed against his strength and cunning. Usually he had been able to use his long fangs, but now this man creature gripped him by the throat and he was powerless. The more he struggled, the more helpless he became. His breath whistled through his nose in sobs and his eyes grew dim. The world reeled, and he fell to earth panting and entirely exhausted. For the moment, the man creature had conquered him.

Then, while Roderick's two companions held the ropes taut, pulling in opposite 
directions, Roderick slipped a stick about a foot long between the wolf's jaws, pressing it back into his mouth as far as possible. He then took a stout cord and passed it in front of the stick, upon one side of his mouth, over his jaw, and behind the stick on the other, thus making a tight lacing like a letter $\mathrm{X}$. When he had finished and drawn the cord tight and tied it, the wolf's jaws were held as in a vise, and he was as harmless as though he had no fangs with which to strike.

Then they slacked the two ropes a bit and gradually breath and strength came back to poor Hairface. He soon struggled to his feet and sat up, glaring about him impotently. He reached up his paws and tried to poke the stick from his mouth, but it would not budge. He growled and roared and threatened, but all to no purpose. As soon as he became too violent, the two nooses that still gripped his throat choked 
him into submission; do what he would, he was powerless.

Soon the two man creatures, whose throats he would like to tear open, began drawing him through the woods, each holding him at a distance with the taut rope, and he was obliged to follow where they led. The ropes were resistless. If he became too violent, they cut off his breath, and left him gasping and panting upon the ground. His dog intelligence soon taught him that submission was the better course, and he went along reluctantly, abiding his opportunity for revenge.

For hours this strange company plodded through the woods. It was slow work, as the ropes continually got tangled in the underbrush; but finally the boys saw that their prisoner was really harmless with the stick in his jaws, so they relaxed the ropes, and one went ahead and the other behind. Just about sundown they reached the vil- 
lage and it was a curious and astonished crowd that soon congregated to see their captive. The more timid of the citizens urged that the wolf be dispatched at once, but Roderick would not hear of it.

"I tell you he is half dog," he reiterated again and again.

Old trappers and hunters viewed him warily and then shook their heads. "He may be part dog," was their verdict, "but he looks like a full-blooded wolf, with the exception of the long hairs upon his face, and this may be merely a freak."

It was the concensus of opinion that for Roderick to try to keep him and tame him was a hazardous undertaking, but Roderick was Scotch, and no Scotchman ever changes his mind from external pressure. So he took the wolf-dog, as he persisted in calling him, to his own home, to the great alarm of his mother, and put him in a box-stall in the barn, still keeping in his mouth the 
stick which locked his jaws, and also fastening him with two collars and a chain. One of the collars was about his neck and the other about his body behind his fore-legs, and they were joined together.

In the darkest and most remote corner of the stall, Hairface cowered, glaring and snarling at all who came near him. His yellow, hungry, hate-filled eyes were the eyes of a wolf. No gleam of affection ever softened them. He was uncompromising in his hatred for man, who had undone him.

Although Roderick spent hours talking to him and offering him food and water, he seemed to make no headway in subduing his wolf nature. The water he would drink, when no one was by to see, but food he did not touch. Perhaps he remembered the old wolf's training, which prescribed that the pack should eat nothing that they did not kill themselves; or it 
may be he thought the meat put before him might be poisoned; or possibly it was the man taint about it that offended him. Certain it is that for nearly a week he refused all food.

When at last even Roderick despaired of keeping his wolf-dog, and was seriously considering the advice of those who counseled shooting Hairface, the wolf began to eat. First it was a rabbit that Roderick had just shot for him. This meat was still warm with the warmth of nature, so could not be poison. Having been relieved of the stick that locked his jaws together, the half-famished wolf-dog, when left alone, tore the rabbit to bits and ate it ravenously.

After that there was no trouble about his eating. Little by little, he began to take cooked food, such as any dog would eat; but the man taint about all his food troubled him for some time, and he would sniff at it suspiciously before beginning his meal. 
This much Roderick had accomplished in a month's time. The wolf trusted him enough to eat what he set before him, but that was about all. Whenever his master came too near to him, he would crouch as though to spring, and bare his fangs and snarl. If his master extended his hand toward him, the hair upon his neck would stand on end, his lips would part, showing his fangs gleaming white, and he would growl savagely.

"You can't do anything with him," said Hugh one day, when he had come in to see the wolf and to learn how Roderick was getting on with him.

"Well, I have got him to eat," replied the wolf's jealous owner, "and perhaps I'll fetch him yet. Anyhow, he is worth trying. I have a good mind to put my hand upon him. I don't really believe he would bite me."

"Don't try it," cautioned his friend. 
But Roderick was deaf to his companion's warning, and slowly advanced toward Hairface, holding out his hand, and talking to him softly all the time.

The wolf-dog crouched in his corner, glaring at his master, and growling continuously. Lower and lower to the floor he slunk, as Roderick's hand approached his head, and his growl took on a warning throaty quality.

"Look out, Rod," cried Hugh, but he spoke too late. Quick as a flash the wolf struck. Roderick snatched his hand back with the greatest dexterity, but he was snail-like compared with the movements of the wolf-dog, who sank his fangs deep in the flesh. The boy quickly retreated to the barn floor, shaking his bleeding hand, and furious at his untamable prisoner.

In a fit of temper he seized his rifle and raised it to his shoulder, but at the motion Hairface slunk into his corner and looked 
up with fear in his eyes. He clearly understood the deadly intent of the man creature. For a moment Roderick hesitated, and then relented.

For Vixen's sake, he would give him another trial. After all, he owed something to Hairface for having robbed him of his mother. Perhaps he would conquer the wolf in time, if he were patient. 


\section{CHAP'TER VII}

\section{BACK TO HIS FIRST LOVE}




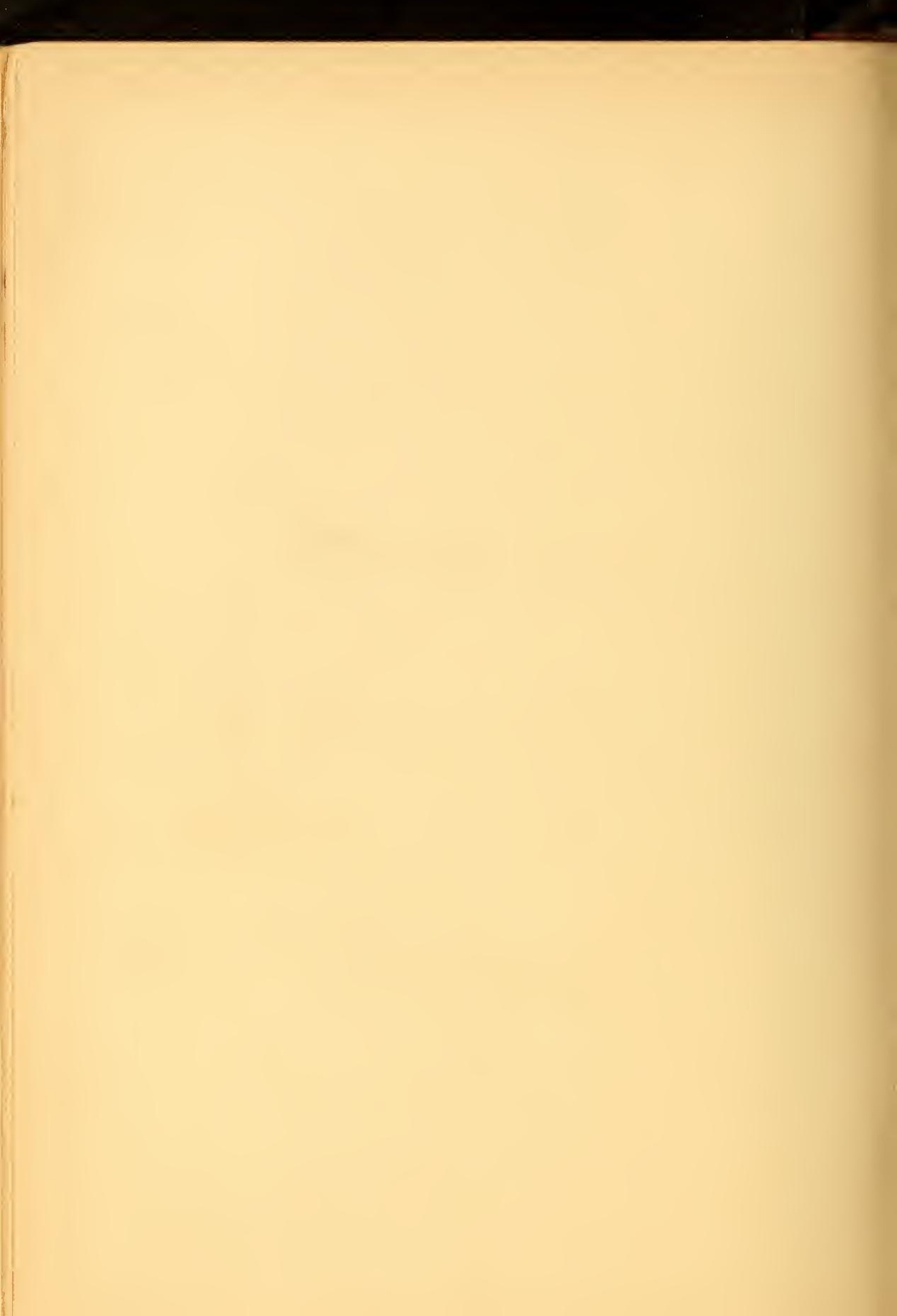




\section{CHAPTER VII}

\section{BACK TO HIS FIRST LOVE}

MAN was the first love of the great gray timber wolf, who himself was the wilderness dog. Until he at last came to know and love man, this finer passion of the heart had never touched him. He had loved his mate in the mating season in his harsh way, after his kind, but no other tender sentiment had ever stirred his heart until he rubbed against the leg of primeval man, who was almost as much of a wild beast as he. They had often met on the mountain-top and in the deep valley, at the fording of the stream and in the dark thicket, yet for long they were strangers.

There was something about this erect, self-reliant man creature that fascinated the 
wolf. This two-legged animal had such fearful powers over the other animals and over the forces of nature. He could bring fire from two sticks, which of themselves really possessed no warmth. $\mathrm{He}$ could draw fish from the stream with a small cord. With a stick he could bring birds down out of the sky, and the strong, fleet buck, that the pack would have to follow for a day to haul down, stopped at his bidding and lay dead on the ground.

This man creature, too, lived in a den that he fashioned for himself above the solid earth, while the wild beasts lived in holes and dens under the earth. He could make the night bright with his camp-fire, when there was ho moon, and could warm his den with that mysterious dancing brightness which held such terrors for the wild beasts. $\mathrm{He}$ could catch the wild horse, which was fleeter than a wolf, and make it carry him far over the prairies. 
Is it any wonder that such a creature finally drew the wolf to him and made of his foe a friend, as he has done with so many of the beasts of the field?

When the wolf took man for his master, he put off hate, and love entered his heart; such love and fidelity as man has never received from any other of the wild creatures.

Man was also the wolf-dog's god ; a creature that he could worship, a being for whom if need be, it was sweet to die.

But poor Hairface, crouching in his corner of the box-stall and glowering at the man who confronted him, was neither a dog nor a wolf, but a wolf-dog. He had been born upon the boundary line between the domestic and the wild creature. Had Roderick found him that spring when he searched for the den in the rocks, he never would have been a wolf at all, either in disposition or in habits of life; but the old wolf found him instead, and in two years 
under his guidance had taken him entirely back to the wild. Now he was a wolf from the tip of his massive jaws, which were so eager to sink their fangs into human flesh, to the end of his bushy tail, which was also the typical wolf banner. There was one thing, however, about him that was still dog. Nothing could change this fact. The blood of the old deerhound ran in his veins, and sooner or later would assert itself.

It was because of this that Roderick waited and was patient, when all his friends clamored for the life of Hairface.

He also remembered a scene in the thicket on that spring morning when the dying hound had licked her master's hand as she gasped out her last breath and forgave him, although he had taken her life. Surely he could forgive Hairface for sinking his fangs in his flesh, provided he overcame him at last.

Indeed, the good seed was already sown 
and taking root, although Roderick was slow to see it. Hairface trusted him, for he now ate the food which his master placed before him, and to trust in one way was a sign that he would soon trust in others.

About a week after the first sad experience when Roderick had attempted to lay his hand upon Hairface, he tried it again. This time the wolf-dog growled and bristled as before, but instead of striking when the hand approached within reach, he slunk farther and farther into the corner, turning his head lest he might again bite his master, or so Roderick interpreted it.

So much, at least, had been gained. $\mathrm{He}$ no longer wished to bite his master. This was a great step, and with another week of patience Roderick was able to put his hand fairly upon the massive head, and stroke it, although the process was not pleasing to the wolf. One peculiarity, however, Hairface always retained, even after he had 
come to love his master as deeply as any dog could have done. He always reached out to meet the proffered hand with his jaws. He never allowed it to be put directly upon the top of his head. First it must pass by those upturned jaws.

This is a wolfish trait that many dogs possess; a remnant of the wolf's lack of confidence in man. He must first see for himself, and then, if all is well, will suffer the hand to approach him.

Once they had got this far, the friendship between Roderick and his wolf-dog grew rapidly.

Finally, to the consternation of the good people of the village, the boy took the double collar from Hairface and led him about upon an ordinary leash, just like any other large dog.

"Mebbe you can tame a wolf, mon, and mebbe you can't," said Robert Killdare, an old Scotch log-driver of the place. "A 
wolf he war born, an' a wolf he will always be, I am after thinking. If ye wake up, Rod, some fine morning and find yourself eaten up, don't say I dinna tell you, that's all, mon."

But the dog nature, which was as much a part of Hairface as was his long gray coat and his whip-cord sinews, even now had asserted itself more than Roderick dreamed. In the dark corner of his box-stall the seed had germinated as Hairface watched this man creature coming and going.

Surely he was the same in kind as that wood-cutter, whom the whelps and the old wolf had shadowed for nearly a week the fall before, and of whom the old wolf had tried to make them so afraid. Yet this man creature seemed full of kindness. His voice, when he talked to Hairface, did not convey any menace. On the other hand, it was low and pleasant and reassuring. Could it be that his sire, the 
old wolf who knew the wilderness so well, and whose knowledge of men so far surpassed his own, had been mistaken, or was there a difference in these men creatures just as there was in wolves? Hairface himself was not like the Mongrel, so perhaps this man creature was not like that other whom they had watched in the woods.

Instinctively, Hairface felt that the villagers, whom they met upon their walks when his master led him about the town, feared him, and this pleased the wolf-dog. The Mongrel had feared him. Perhaps all the men creatures with the exception of his master were like the Mongrel. That was the way in which Hairface finally classified the world of men. Those who did not fear him were strong like his master and to be respected; those who did, were mongrels to be despised.

When Hairface had first been tied in the stall, with his jaws locked tightly 
together, he had been all hate. There was not a hair upon his back and neck that did not bristle whenever any one came near him. He was fairly bursting with rage. They had undone him, taken away his freedom. If he ever got loose, he would kill them all.

After a week or two, however, a new feeling, that was foreign to him, stole softly into his nature. He began to watch for the coming and going of this man creature who had such strange power over him.

At first, when Roderick talked to him, it would put him into a rage,-the man creature was taunting him; but gradually he came to love the tones of his voice, and to miss them when he did not talk.

Slowly the feeling inside him, which was so different from the wolf hate, began to assert itself more and more. He did not wag his tail or laugh at his master's coming, as a dog will often do, but his all- 
seeing yellow eyes followed his every motion, and this was the first sign that he gave of love.

Never in his life, even when he grew to love his master as devotedly as any dog, was he demonstrative. His love was always silent, a smooth current that ran deep. $\mathrm{He}$ had lived too much in the woods, in the vast silences which subdue the lives of those who dwell in the echoless depths, to be a creature of enthusiasm or noise.

So, although Hairface trotted as obediently at heel as any dog and was quick to mind his master, the villagers distrusted him. He was no dog, and no part of him was dog. He did not love Roderick or he would wag his tail or show some other sign of affection. He was a wolf, grim and terrible, silent and unloving. This was the general verdict; although the young Scotchman argued and expostulated, he could not change it. 
"A wolf he was born, mon, an' a wolf he will die. You canna get figs from thistles, an' no good will come on't." This was the way in which Bobbie McGinnis regarded the wolf, as the inhabitants of St. Boniface persisted in calling him, to Roderick's great disgust.

All the dogs in the village, too, considered Hairface an outcast. They recognized only the wolf in his nature, as did the men. Most of them put their tails between their legs and slunk away whenever Hairface came in sight. So he at once classed them as mongrels. They had not courage like himself, and Hairface accordingly despised them.

There were two or three, however, of better stuff than their fellows, who were not afraid of anything, having bulldog blood in them. One evening these fell upon Hairface, when he had loitered for a moment behind his master, and there was straight- 
way such a fight as had not been seen in the village in many a day. It was three to one, but that made no difference, for this one was a born fighter. He had been trained to fight from the moment that he could stagger about.

His motions were like lightning, and his powerful jaws worked with deadly effect. He did not clinch, as the bulldog likes to do, but sprang and snapped and then sprang again, and each time he punished his adversary as only a wolf can.

In less than a minute, one of the dogs was lying upon the ground weltering in his own blood, gasping out his life; and a second had turned tail and run. The third still faced the wolf, but only the intervention of men saved his life, for Hairface was leaving deep gaping gashes each time he struck.

This dog fight, although the dogs had been the aggressors, also helped to put 
Hairface in disfavor, and there was again a clamor for his life; but Roderick laughed such entreaties to scorn.

" $\mathrm{He}$ can lick all the dogs in town in a bunch," he would say. "If you don't believe it, just bring them on."

About this time, Roderick again resumed the driving of the tote-team to the lumbercamps far in the heavily-timbered wilderness, and took his wolf-dog with him; so the villagers had nothing further to complain of for that winter.

It was surprising with what whole-heartedness Hairface gave himself to his master, once his wolf nature had been displaced by the dog nature in him; although, as he was undemonstrative and silent, no one ever knew the depth of his affection but Roderick, who had understood him all along.

Following the tote-team through the snow-laden woods was much more to the wolf-dog's liking than staying in a village. 
Here was in part the old free life which he had lived in the wilderness, and at the same time here was his master, who was his new-found love.

He usually ran in the trail behind the sled, but often ranged in wide circles across the road looking for rabbit or partridge signs, and at the same time keeping an eye upon the team.

In the lumber-camp the wolf, as they called him, was not much more of a favorite than he had been in the village, for even here the rough lumbermen, inured to all kinds of danger, were afraid of Hairface. He was so silent and unapproachable that they could not believe him to be anything but a full-blooded wolf.

Hairface was always on his dignity with the lumbermen and did not allow any of them so much as to put a hand upon him. In fact, Roderick was the only person who ever dared touch him. 
"Can't make me believe that there is any dog about that critter, Rod," growled an old lumberman one day. " $\mathrm{He}$ is wolf, and nothing but wolf, and he doesn't care any more about you than he does about a stick. $\mathrm{He}$ can't care ; it ain't in his nater. $\mathrm{He}$ is a wolf, all fight and hate."

"He'd go through fire for me; I know it," replied the boy stoutly.

All through the winter, Hairface and the tote-team came and went in the silent forest; but in the spring something happened that amply bore out Roderick's assertions as to the loyalty and affection of his wolf-dog, forever silencing his critics in the lumber-camp at least.

This year the camp was in a new region and a part of the lumber was cut near a deep gulch, which led down to a branch of the Ottawa. To save drawing the lumber to this river, the lumbermen dumped it all into the bottom of the gulch and built a 
dam across it below the logs. They knew that in the spring, when the heavy rains came, the gulch would fill; and when this occurred, they planned to dynamite the dam and let the water, lumber and all, go down to the river in a mad rush. This is a common practice among lumbermen, who will resort to almost any expediency to get rid of hauling the logs.

In the spring the rains came just as they had expected, and the valley was filled with water until even with the top of the dam. By this time the trips of the tote-team had been given up and Roderick was temporarily helping the rivermen get the drive started. On the day that they were to dynamite the dam, there was great excitement, for it was an awful yet inspiring sight to see this mountain of water sweep millions of feet of timber down the gulch to the river. If all went well, when the last small stream had run out, the logs would be 
down in the river; but it sometimes happened that the logs jammed midway in their course, allowing the water to run out, but leaving a part of the timber in the middle of the gulch.

While the rivermen were making ready for the blasts that should unloose the turbulence of the waters and set the lumber in motion, Hairface sat gravely upon the bank, his eyes riveted upon Roderick as he walked from point to point upon the logs, freeing one here and there with his spike-pole and making sure, so far as possible, that all would move out smoothly when the time came.

Finally all was ready, and the charges of dynamite were set off. Tons of water and mud were thrown up by the explosion and the timbers of the dam were tumbled in all directions. Then what a turmoil filled the valley, where but a moment before all had been quiet and calm! With a roar like con- 
tinuous thunder, foaming, lashing, and tumbling, the waters poured through the broken dam, and the mighty mass of lumber started on its way to the river. The logs that a moment ago had seemed inanimate suddenly took to themselves life and motion. They butted and fought like mighty battering-rams. They rolled and twisted, groaned and scraped, each doing its best to shoulder its neighbor out of place, and all fighting for the right of way.

Once the mass had fairly started, the courageous rivermen were upon it with their spike-poles and Peavy sticks, pushing and prying, exerting themselves to the utmost to see that the drive went down to the river without a hitch. As Roderick was borne farther and farther down-stream by the moving logs, Hairface followed upon the shore, watching his master's every motion.

But this short drive was doomed to miserable failure, for it had not gone over a 
quarter of the distance to the river when the logs began to jam, and where there had been confusion before, there was now pandemonium. Fiercer and fiercer grew the struggle of the fighting logs to get over the jam. They butted and pushed and every moment the current behind them piled them up higher, until in places they were mountain-high; all seething and tumbling, crashing and grinding. It was in such a death-trap that Roderick suddenly found himself, several rods from shore.

The logs danced and leaped so that he could hardly keep his footing. Great chasms suddenly yawned at his feet, endeavoring to engulf him, and then, with a sound like thunder, closed. He sprang from point to point, avoiding death at every leap by a hair's breadth.

In this frightful scene, all had forgotten the wolf-dog; but presently, above the thunder of these millions of feet of fighting 
logs and the roar of the mad waters, was heard a long pathetic howl, cutting the great volume of sound like a knife, and Hairface sprang from the bank upon the jam.

Dog though he was, without retractile claws to keep his footing as he sprang, he jumped from $\log$ to $\log$ with the precision and dexterity of a great cat. He cleared eight and ten feet at a bound and his paws barely touched the logs, as he sped to his imperiled master. Hairface had nearly reached Roderick's side, when the log upon which the boy stood suddenly shot up at one end and the young Scotchman was thrown heavily, the end of the beam barely missing his skull as it fell. With a single bound Hairface was at the side of the prostrate figure. Instantly, another gap yawned before them; closing his teeth upon his master's coat collar, the wolf-dog dragged him back several feet to safety. 


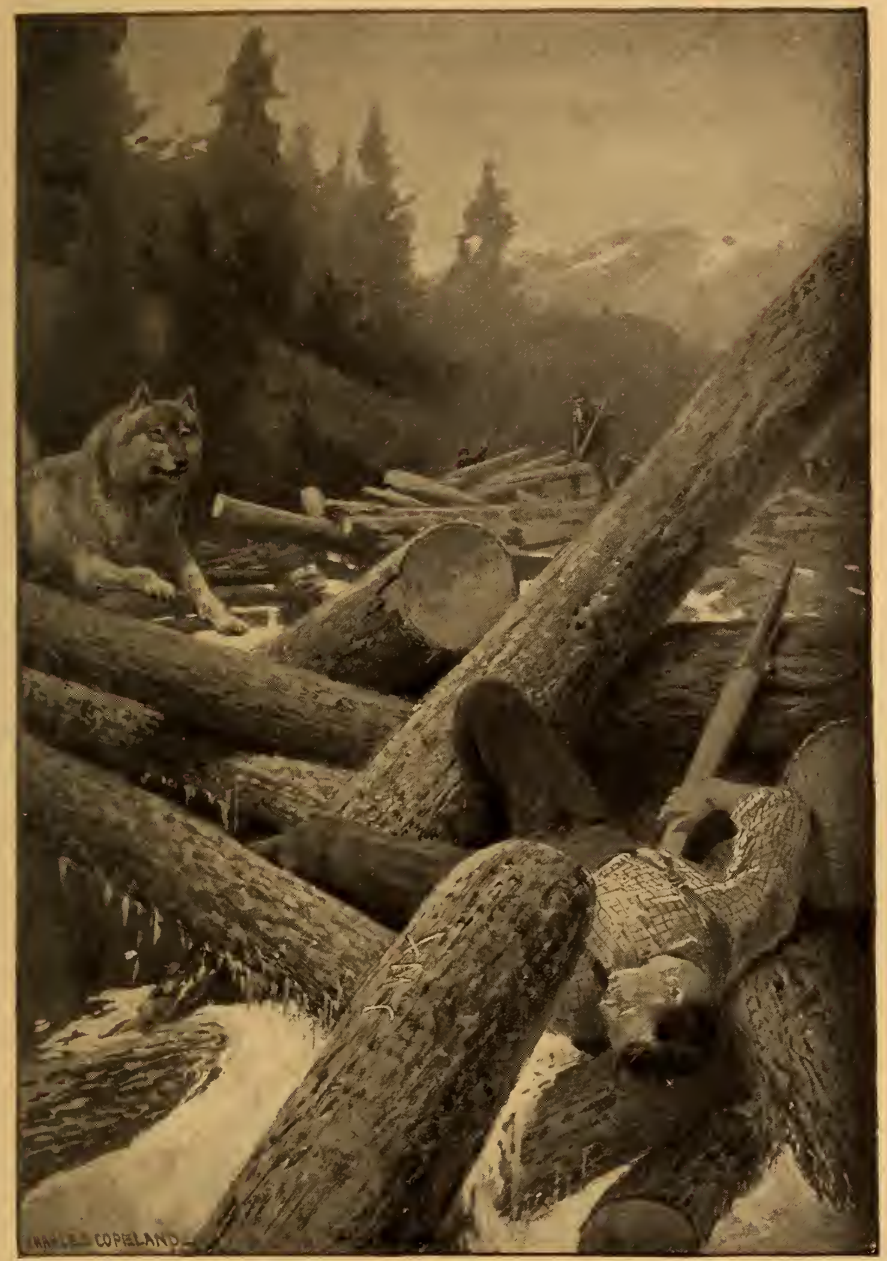

Hairface Sped to His Imperilled Master 

Death was all about them, and the most that Hairface could do was to haul his master this way and that and keep him from rolling between the logs. But this temporary aid was just what stood between Roderick and a terrible death, for his companions were coming to his rescue, leaping from $\log$ to $\log$.

The jam was so thoroughly packed that its pounding and pushing each second lessened. The rivermen, who were now at Roderick's side, lifted him in their strong arms and bore him over the jam to the shore.

When they laid him on the solid earth, Hairface snuggled up as close to his master as he could get, licking the blood from his face and washing the dirt from his hands with his soft, long tongue. He was nearly frantic with the deathlike stillness of his master, and when Roderick at last opened his eyes and stroked his head, he barked again and again with delight. 
"Just that moment's help, when Hairface pulled me out of the way of that $\log$ and then kept me from falling in between two others, was what saved me," he said as soon as he could speak. "I saw the danger myself but was too faint to move. What do you boys think of my wolf now?" Roderick continued triumphantly. "I guess he is about worth his weight in gold." 


\section{CHAPTER VIII}

\section{FAITHFUL AS A DOG}




\section{CHAPTER VIII}

\section{FAITHFUL AS A DOG}

ON the last trip of the tote-team out of camp and back to the settlement, still another incident occurred that showed Hairface's fidelity to his master.

When about half-way back to McGregor's Point, Roderick missed his wolf-dog. This did not disturb him at first, as Hairface often ranged wide along the trail, looking for rabbits or other game; but, when an hour passed and he did not appear, Roderick thought it strange and whistled from time to time. All in vain, for Hairface had not rejoined the team when the Point was reached.

"He's left you, mon," chuckled old McCormick. "Gone back to the wolves just as the deerhound did." 
Roderick stoutly denied this, although he was sorely troubled by the incident.

When, the following morning, Hairface had not returned, the boy went along the trail to look for him, going horseback and taking his dinner.

Nothing was seen of the missing wolf-dog until he rounded a sharp twist in the trail, at about the spot where Roderick had first missed him; there he came upon him, lying in the rough road, close by an old coat of his master's which had accidentally fallen off the load.

When he saw Roderick, he leaped about with great glee and continually ran back and nosed the garment, as much as to say, "Here it is, master. I have been guarding it until your return."

A dog might have picked up the coat and followed with it, but not so the wolf. His kind had not acquired the habit of retriev- 
ing, so he stayed faithfully by his master's property.

It was a very slight incident, yet it brought a great lump into Roderick's throat, coming as it did so closely upon the scene at the log jam. The young Scotchman dismounted and sat upon the ground, hugging his great wolf, while Hairface licked his face and hands, feeling well pleased with his day's vigil.

Once back in the parish of St. Boniface, Roderick and Hairface took up their old duties of farmers, which had been temporarily interrupted by the winter's work with the tote-team. The wolf-dog's rescue of his master from the jam gained him a few friends among the villagers, although he was still viewed with disfavor by most of them.

This summer Roderick determined to make a sheep and cattle dog of Hairface and began training him as soon as they 
were back upon the little farm. He took great pride in developing his wolf, so that, before the summer was over, Hairface was one of the best sheep and cattle herders in the valley of the upper Ottawa.

It is doubtful if it would have made any difference in the young Scotchman's resolve, had he known in how many bloody forays upon sheep Hairface had participated. The great gray wolf often recalled times in the past, when he and his sire and the Mongrel had scattered these flocks of stupid creatures to the wind, and then killed them right and left.

It was a striking picture to see the tall wolf guarding the white innocent sheep; his hungry yellow eyes watching warily to see that harm did not come to them. His kind had been their sworn enemy for all time, but now the "lion and the lamb" were lying down together.

About the first of October something 
happened in connection with the sheepherding that tested the sheep-dog as no other event could have done, and showed how utterly he had become dog, the sworn ally of man.

It was about the middle of October, Indian summer in this cold northland. A dreamy blue haze was spread like a pale, transparent veil over all things. The sun's rays were mellow, like the soft smile of the dying year, and the air was clear and cool.

Hairface and his flock were upon a sidehill, close to an evergreen wood of spruce and hemlock. The sheep were feeding and the wolf sat upon his haunches, his restless yellow eyes roving this way and that.

Presently, two tall gaunt figures, as mighty as the sheep-dog, slunk through the cover toward the open pasture-land, and stood in the thicket peering out at the sheep and their guardian. It was the old wolf, the 
sire of Hairface, and also his litter brother, the Mongrel.

They remained still for a few minutes testing the air, until they had analyzed both the scent of the flock of sheep and that of the sheep-dog. They knew at once that it was their comrade of many a sheep-killing, for a wolf's nose never forgets. They also understood intuitively, by his attitude of watchfulness over the sheep, that he had turned dog and gone over to their enemy, man.

With manes up and their fangs bared, of one impulse they started forward to kill this wolf who had turned dog and now guarded the sheep of their enemy, man, the sheep who were legitimate food for wolves.

Hairface saw his sire and the Mongrel almost as soon as they did him. Here were two wolves, the enemy of his friend man, who had come to destroy the sheep that 
belonged to his master, and he sprang forward with bristling mane, raised hackles and gleaming fangs to kill these sheep destroyers. Dearer to him than life was his master; so what mattered wounds or even death if he might die fighting for the man creature who was his god?

The old wolf and the Mongrel came on furiously, without fear; but Hairface was wary. He had developed his dog traits, and they had not. He knew full well that, if he were to win this fight, he would need all the cunning of the dog as well as the fierceness of the wolf.

He backed up against a juniper bush, that his flank might be partially protected, and prepared for the attack. He did not have long to wait; for, without any parley or sparring, the old wolf and the Mongrel were upon him.

They sprang in together like trained fighters, and Hairface had to take the pun- 
ishment of one while he punished the other; but his coat was much thicker than that of either of his antagonists and this stood him in good stead.

There was no barking, but desperate fighting. They sprang like flashing gray streaks, and their long jaws worked like machines. Fang struck shoulder and shoulder met fang, and the blood flowed in small trickling streams down their sides.

Soon both of Hairface's ears were in ribbons and still he fought on. His sire, the old wolf, had the skin at his throat ripped open so that it hung in a loose flap, but he did not mind a little thing like that.

Hairface's own fangs then met in the Mongrel's shoulder and he fought on three legs. The old wolf punished his traitorous whelp with a great gaping wound in the throat, but he was nothing daunted. They should not kill his master's sheep until they had killed him. 
Again they both sprang together and all but knocked him off his feet. Had this happened, his hour would have come, but he was up like lightning and gripped the Mongrel by the throat. He sank his teeth deeply and then sprang back, taking a part of his hold with him.

This stroke probably saved Hairface's life, for the Mongrel's jugular vein was torn open, and with a gasp he sank to earth and did not rise again. He kicked feebly and soon lay motionless. His part in the fight was over.

Still the old wolf kept up the struggle. Clearly, however, he was no match for Hairface, who was fighting for his master's sheep, while the old wolf was merely fighting for victory. Steadily the wolf-dog bore his sire back toward the woods, until at last, still putting up a running fight, he disappeared in the thicket.

Hairface soon returned. Sitting down 
on the hillside near to his sheep, he began to lick his wounds. He was so spent with fighting and loss of blood that he could hardly stand, but this was nothing, as long as his master's property was safe.

That night, when Roderick came out to salt the flock, he found his wolf-dog still guarding them, but so stiff that he could scarcely move. Upon interrogating him, Hairface proudly led the way to where the Nongrel lay dead, and, after looking over the ground carefully, the young Scotchman understood. So once more he sat down upon the ground and put his arms around the neck of his faithful friend.

A week or two after the encounter between Hairface and his kin, Roderick decided that it was just as well to bring the sheep home. It was growing cold rapidly and feed was short and dry. There had been no losses whatever during the year, under the watchful care of Hairface, and 
he did not want anything to happen now to break this fine record.

So the sheep were driven home, the corn was husked, and the farm buildings were made snug for winter.

The snows fell early and by the middle of November there were six inches on the ground, while the skies were a dull leaden gray which promised more.

This was good news for Roderick and Hairface, for it meant that they would soon go back to the tote-team, and both liked the wilderness better than they did the primitive village life.

To Roderick, as to his wolf-dog, the smell of spruce and hemlock and the gray vistas of the forest were satisfying as only untrammeled nature can be. They were never lonely in the woods, which teemed with life and were full of low, sweet voices. If one listened long and intently, he could even hear the breathing of the forest, a 
deep rhythmic soughing, coming at regular intervals, like the low gasps of a mighty bellows.

About the middle of December, Bill Holland, the chaney man whose duties were timekeeper and paymaster of the camp, was taken sick, and Roderick was put in his place for the time being. The young Scotchman was a good mathematician and capable of better things than driving the tote-team, which he had been doing partly for fun ; so he kept the job even after Holland had partially recovered and gone back to civilization.

This camp was a small one, and the chaney man was also the scaler, measuring all the logs as they were cut and piled.

Roderick's new duties kept him busy from morning till night, and also brought him into very intimate relations with the men. 'The timekeeper and scaler' who had 
preceded him had been very slack in his duties, and had always played into the hands of the men in the matter of keeping their time. $\mathrm{He}$ also was not particular about the way in which they cut the logs. This was done to curry favor with the camp. But Roderick's Scotch conscience would not let him continue any of this favoritism, which was really sharp practice. So he docked the men whenever for any reason they did not give in their correct time. $\mathrm{He}$ also made them butt their logs carefully and saw them close to the ground.

For this he at once became unpopular. Besides, he was young, and had jumped into his position over the heads of some of the rest of the help, which also made jealousy.

With every day that went by the feeling grew, until, at the end of a month, Roderick and Hairface were almost outcasts in the camp. None of the men spoke to Roderick 
unless they were obliged to, and Hairface was hated even more than he had been the year before.

Such a thing might not have happened in an intelligent community, but this was one of the roughest camps upon the upper Ottawa. Its members were gathered from all quarters of Canada, although most were either French, Canuck, Scotch, or ScotchIrish.

The trouble between Roderick and the men probably never would have been very serious had not Whiskey Jake, a rumseller from McGregor's Point, smuggled liquor into the camp. As it was against the regulations to have liquor, he came in the evening, bringing his goods in a sleigh, and departed before daylight; but he left behind him several large demijohns, and the effect of his visit was at once apparent in the demeanor of the men. The boss was also away for a few days at this critical time, 
which made them under less restraint than they would otherwise have been.

They had treated Roderick with silent disdain before, but now they openly jeered and leered at him. This attitude of the men grew worse and worse as the days wore on, and Roderick hoped and prayed that the boss might return or that the bad whiskey might give out.

At last the trouble reached a crisis when the young Scotchman refused to scale a log unless it was rebutted, saying that it could not be sawed as it was, and that it would have to be done at the mills if it were not done now.

Instantly, there was a storm among the men, and an excited crowd gathered around the scaler. One of the men, Mike Mahoney, the bully of the camp, and head chopper, swore that Roderick would scale the log or he would kill him.

But Roderick came of a race that had 
died for their faith, and the threat of the bully had no terror for him, although he was backed by a dozen ruffians, who were half drunk, and all anxious to help pound him.

Mahoney laid a heavy hand upon the young man's shoulder and glowered upon him, but Roderick looked straight in his bleared eyes, his own clear blue eyes glinting like steel.

"Whatever you fellows see fit to do, I shall not scale that log until it is squared up at the butt," he declared, in a quiet, ringing voice, in which was not a tremor.

This declaration was the signal for a roar of anger from the men and a combined attack, which, in a second, attained the fury of a football rush. Mike's heavy fist was aimed at Roderick's head, but he warded off the blow by a hair's breadth and returned the bully one in the face.

It was a hopeless fight, however, for in 
five seconds the brave young fellow was down and a dozen reckless men, so crazed with whiskey that they hardly knew what they did, were kicking the life out of their victim with their heavy boots.

"Stop, we'll kill him," warned one of the gang, who was a little less intoxicated than his fellows.

"That's what we intend to do," growled Mike. "Boot him, boys, boot him."

Just at that second there was a change in the program, which could not have been more sudden if a ten-inch shell had been thrown in their midst and burst at the very heart of the fight. A tall, gaunt, gray figure, making fifteen feet at a bound, came out of the woods like a cyclone and landed with a last mighty leap full upon the top of the struggling mass.

It was Hairface and his fury was terrible to see. His mane and hackles were up, and his cavernous mouth was open, ready for 
the death-dealing snap. Every inch of his one hundred and twenty-five pounds of whip-cord sinews and his rawhide muscles seemed bursting with rage. The horrible sound, half snarl and half roar, that came from his throat as he sprang, was enough to freeze the blood in the veins of the terrified lumbermen.

Right and left he ripped and slashed with his mighty jaws. Here he tore open an arm, there he laid a thigh-bone bare and white; but by good fortune he happened not to strike at any man's throat.

Roderick, at the bottom of the heap, heard the snarl, and knew well what it meant. Although he instantly understood that his wolf-dog had come in just the right moment to save his life, a great fear seized him. Unless he could free himself and stop the enraged brute, he would kill half of them. No one knew how Hairface loved his master. His fury was terrible. 
"Hairface, back," he called through the struggling mass. "Back, I say, Hairface; back."

With lightning-like haste those who could struggled out of the mass, and fled in every direction, each for himself. They were almost as white with fear as was the snow upon the ground; their eyes bulged out from their heads, and their teeth chattered.

At the sound of his master's voice, Hairface paused for a second in his deadly work. In that second Roderick reached up his hand and catching hold of the long coarse hair upon his neck, spoke gently to him. The wolf-dog still continued to growl like a demon, but he stopped long enough to lick his master's hand.

"Now, men," called Roderick, "pile off as carefully as you can and I will hold him."

As fearfully as though they were working 
with dynamite, the men untangled themselves and stood erect, as astonished and terrified a set of lumbermen as the Canadian woods had ever seen.

Roderick was covered with bruises and blood flowed freely from a cut upon his head, but otherwise he was not injured.

Hairface stood by his side, still raging, all eagerness to get at his master's enemies. "Boys," said Roderick, as soon as he got his breath, "you might have killed me had it not been for Hairface, and I feel he has saved you as horrible a fate as he has me. But I know that you are full of whiskey, and not more than half responsible, so I am going to overlook it this time, with one exception. I feel that you have been the tools of an unscrupulous man, whom we will be well rid of."

Then, turning to the bully who had led the attack, he said: "Mike, you git. I will give you just two minutes to do it. 
When that time is up, I will let Hairface at your throat."

One glance at the wolf-dog was enough for Mike. He turned without a word and, not even stopping for his cap, which had been knocked off in the scrimmage, took the trail for McGregor's Point, at the best pace of which he was capable. Hairface followed him with his blazing yellow eyes until the blue-green plumes of the forest hid him from sight. 


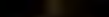




\section{CHAPTER IX}

\section{HEARD IN THE SILENCE}





\section{CHAPTER IX}

\section{HEARD IN THE SILENCE}

In the latter part of February of the same season when Hairface had rescued Roderick from the fury of the lumbermen, the young Scotchman was sent across country to a neighboring lumber-camp. Here for a day or two he was to help with the scaling of the logs, the local scaler having been taken sick, which had caused the work to get behind.

There had been a glare crust for several days, and Hairface, who had been hunting assiduously, had cut his feet so badly on the crust that he could hardly stand; for the first time in two years, therefore, he was left behind. His master tied him in the stable and explained to him, as well as he 
was able, that he could not accompany him, and was not to make a fuss. At first the wolf-dog was nearly heart-broken, but Billy, the stable-boy, was very good to him, and he finally decided to make the best of a bad matter.

The second day after Roderick's departure, it began to snow, and all day and all night long it came down steadily. Toward the following noon, the storm ceased; and men and teams were soon busy breaking out the camp and the log-roads, which had become badly blocked.

About five o'clock Billy, who was bedding down the horses and making them snug for the night, noticed that Hairface was whining as he lay asleep in his corner.

Thinking that the dog was the victim of a bad dream, Billy went over and spoke to him ; to his great astonishment the wolfdog leaped up with bared fangs and glaring 
eyes. His mane was erect, every hair upon his back bristled, and every muscle seemed quivering with rage.

Billy beat a hasty retreat into a distant corner, while Hairface still stood glaring about, winking and blinking, not yet quite sure of himself, or where he was.

Then his eyes lost the look of uncertainty, and their light was like two glowing coals in a camp-fire. With a sound, half roar, half howl, he sprang against his strong chain. Once, twice, he sprang; the second time the snap straightened and he was free. Straight towards the door he rushed, but it was shut, so he turned to the window. With a mighty bound he went crashing through it, carrying glass, sash, and all, before him.

Billy followed to the opening and peered after him, his eyes bulging with fright. The wolf-dog was running like the wind, belly to earth, making a bee-line through 
the woods, to what Billy could not for the life of him imagine.

Five minutes later a belated teamster came in, declaring that the wolf-dog had gone mad.

"Faith, an' he waz rumnin' like the divil was arter him. No dog in his right mind cuts up such didoes. I tell you, he is mad."

Meanwhile, Roderick had made a successful trip to the neighboring camp, and had completed his work of scaling. The second afternoon, when the storm had ceased, he had started for home, in spite of the remonstrances of the lumbermen, who knew better than he how deep and heavy the snow was and how it would weigh him down.

When he had covered about half of the distance back to the home camp, one of his snow-shoes broke, and it took quite a while to mend it. Not only did this con- 
sume time, but the shoe now gave out at the break every mile or so, and he was obliged to stop to repair it. This, together with the very hard traveling, so delayed him that when night fell he had covered barely half the distance back to camp. At first, his plight seemed more uncomfortable than alarming, for the weather was not so very cold; he would not freeze. To think of making a camp was out of the question, as he had no matches with him. The snow was very deep, but that was not an insurmountable obstacle.

He could not find his way by the stars, as it was cloudy, and there was not light enough for him to travel by the lean of the timber. There was little else for him to do, therefore, but to keep walking so as not to get cold, and wait as patiently as he might for the coming of morning.

About six o'clock, when he had been tramping to and fro in this hopeless man- 
ner for perhaps an hour, a long, highkeyed, desolate howl floated down the aisles of the snow-laden spruces to his ears. He had heard this cry too often to be uncertain as to what it was. He knew it at once to be the hunting cry of the gray wolf.

Then he remembered with some alarm that it had been a very hard winter for all the carnivorous wood folk, a lean year, as lumbermen say. These great brutes must be hungry, and he was unarmed, having gone light in order that he might make a quick trip.

At this point in his thoughts, he detected a slumping sound in the snow near at hand, and, whirling about, saw a wolf, a giant of his kind, standing not thirty paces away, eyeing him hungrily.

In another moment, he heard a similar sound in an opposite direction, and, turning about, beheld another wolf. Presently these 
were joined by two more, who paused at about the same distance away and stood watching him intently.

The sudden appearance of this wolf pack at such close quarters so amazed Roderick, - for he had seen no signs that he was being followed,-that for a moment his mind, usually so alert in a crisis, refused to formulate any plan, and in this moment of hesitation he lost very valuable time.

Being unarmed, his best course was to climb a tree, but he stood with his back against a little poplar until the pack had drawn in so close that for him to select a better refuge than this offered was out of the question.

When this alternative did occur to him, he shinned up the tree for six or eight feet, getting up just high enough to be out of the way of the wolves when they should spring for him; but his position was a most uncertain one. The tree, which barely bore 
his weight, swayed and bent considerably, and the limb upon which his feet rested seemed weak.

In his flight up to this doubtful perch, he had taken one of the snow-shoes with him; but it was a very poor substitute for a club. Besides, he did not dare move about enough to use it, for fear that any movement might either break the limb upon which he stood, or cause the tree itself to bend down so close to the ground that the wolves might spring up and reach him. It was a position that could not be maintained for a very long time, and the question was from what source could any possible help come.

For fifteen or twenty minutes the poor fugitive clung desperately, while the hungry pack beneath tried their best to get at him. At first they came and sat in an expectant circle about the tree, looking up with their yellow phosphorous eyes, their lips wrinkled 
and their fangs bared. Then they tried springing at their prey and at each spring their cavernous mouths opened and occasionally their white teeth clicked, although they could not reach the man within a foot or two.

Then their leader, a taller and more powerful wolf than the rest of the pack, stood upon his hind legs, and put his paws as far up the trunk of the tree as possible, stretching up his sharp nose hungrily.

Roderick thought that the wolf got much too close for comfort, so he reached down with the snow-shoe and aimed a smart blow at the nose. His movements were not as quick as those of the wolf, whose nose was jerked back just far enough to escape the blow, but whose powerful jaws closed upon the snow-shoe; at the same time he leaped to all fours, giving a strong pull upon the weapon.

At first, Roderick thought to keep hold 
of the snow-shoe, but the wolf pulled so hard and quick, and the tree bent so violently, that he let go to save himself. This action was too late, however, for the centre of gravity had been moved so far from immediately over the butt of the tree that, when Roderick released his hold upon the snowshoe, the sapling did not recoil as he had expected, but slowly bent lower and lower, each second bringing him a few inches nearer the upstretched jaws waiting to receive him.

In moments of supreme peril like this in which the young Scotchman now found himself, the mind takes no account of time, but tells off days, months or years, with lightning-like rapidity. It can, when forced to do so, make a marvelous kinetoscope of memory and put years into seconds.

So Roderick, suspended in mid-air, with the yawning jaws of the pack beneath him, recalled many stirring scenes in his life, 
and particularly the struggles of two wolves that he had trapped several years before. Then he had been the victor, but now it was their turn. The wheel of fortune had revolved and he was on the under side.

In imagination he saw his limbs being torn, and the red blood spurting from the wounds. He even saw his bones white and fleshless, as they would doubtless be in another hour. All these and other horrors raced madly through his mind, and cold sweat stood upon his forehead in great drops.

Then the grim, gaunt old wolf, leader of the pack, made a mighty leap and caught the young man by the toe of the boot, holding on just long enough to give a strong tug upon it. This added weight was too much for the brittle poplar, which snapped with a report like the crack of a pistol, bringing man, tree-top, and all, down into the springing, snapping, eager wolf pack. 
The accident was so sudden, and the treetop made such a swishing sound as it fell, that for one moment the wolves sprang back; but, as they saw the man struggle to his feet, they were upon him.

As a dying man clutches at a straw, Roderick reached for the snow-shoe, and, with this poor weapon clenched fiercely in his hand, he made his last stand. $\mathrm{He}$ swung it about his head like one mad, striking in all directions at once, and all the time keeping up a hideous yelling, hoping by mere noise to hold them at a distance.

For a few seconds these tactics worked, but the wolves soon discovered that noise did them no harm and came at him with deadly intent. Again and again he struck them off, but the snow-shoe had no sharp corner. Its ends were nicely rounded, and struck merely a glancing blow. Twice he stunned members of the pack, but in a 
second or two they were up and at him again.

Soon their long jaws began to rip his clothing. First his coat-sleeve went, and then a wolf laid his trousers-leg open for the entire length. His superhuman efforts made his breath come in short gasps. Already the force of his blows was diminishing. A few more seconds and all would be over.

In the very thick of the fight, when the four wolves had sprung at once, and had all but borne him to earth, a fifth wolf, much larger than any of the pack, cleared the near-by thicket at a bound, and with two more great jumps landed fairly in the tree-top at Roderick's side. The struggling man saw him coming, but was too spent to ward him off. Besides, he could not see plainly, for his eyes were dim with the exertion he was making.

Instinctively his hand went down to 
clutch the newcomer by the throat, to dislodge him, if possible; but his grip relaxed almost as it touched the wolf's coat, for it fell upon a stout leather collar, thickly studded with tacks. Frantically he clutched again at the wolf. He trembled so that he could scarcely control his hand. Then a cry of joy broke from his lips. It was Hairface.

Hope, like a bright flame, leaped up in the boy's heart, new strength flowed freely into his exhausted muscles, and he gripped the snow-shoe, crying: "At 'em, Hairface. Give 'em fits. We'll lick 'em yet."

The great dog-wolf, whose heart was fairly bursting with love for his master and with hate for his assailants, needed no urging. Like an avenging fury he fell upon the pack. At the first rush, he caught one of the young wolves in the side of the throat, ripping open his jugular vein, and put him at once out of the combat. 
But in another second the grizzled old wolf, the leader of the pack, was upon Hairface, and the two trained fighters struggled like giants in this death game. They sprang like lightning, and their great jaws met in each other's shoulders and faces. Blood flowed in tiny rivulets. One of the young wolves wounded Hairface badly in the flank, but still he fought on, while Roderick used his snow-shoe with might and main upon the two remaining wolves.

At last Hairface caught the old wolf in the throat grip, and, following his dog instinct, held on. Deeper and deeper he sank his fangs into the old fighter's throat, each second shutting off his wind more effectively. Theleader struggled frantically to free himself, but it was useless. Hairface held him with a grip like steel. Presently he found the jugular vein in the old wolf's throat, and his blood flowed freely. 
This was the beginning of the end, for the old warrior's strength was going; presently he sank down in the snow gasping out his life, and the two remaining wolves fled in panic.

Soon Hairface released his hold upon the old wolf, and stood over him, watching his life ebb. He no longer growled or roared, and Roderick thought the look of rage in his face was replaced by an almost wistful expression. The breathing of the dying wolf grew feebler and feebler. Hairface still stood above him watching, but he did not see the snow-bound forest, or the dying wolf before him.

He saw a moonlit meadow where a patient old wolf taught three eager wolf-dogs to catch mice, and he remembered with pride that the teacher always favored him. He saw the den by the rocks, and the old wolf bringing home a rabbit for his three hungry whelps, while he himself went 
supperless to bed. He saw the pitiless snow-bound forest and the bull moose at bay, while his sire again and again risked his life that he might win meat for his offspring.

Then, as the old wolf gave his last gasp, kicked, and lay still in death, Hairface tenderly licked his face, softly caressing the ugly visage. It was his dog heart that had spoken, for the dead wolf was his sire.

Roderick looked on in amazement until he remembered that Hairface himself had once been a wolf, and then he thought he understood. "Never mind, old fellow," he said cheerily. "It is all in the day's work. $\mathrm{He}$ would have done it to you if he could."

The man's voice aroused Hairface from his dreams of the wolf life. He came and licked his master's hands again and again, snuggled in under his arm and got as close to him as possible, telling him in the 
plainest dog language that his surrender was complete, and that every drop of blood in his body and every ounce of strength in his frame was his master's for all time. 


\section{CHAPTER $\mathrm{X}$}

\section{THE RED RAGE}




\section{CHAPTER X}

THE RED RAGE

Wнат a thing of beauty and grace is the luxuriant primeval forest in summertime; the forest where the profane ring of the axe has never been heard, and where the breast of Mother Earth is still unscarred by the hand of man. What a wealth of life, of growth, of fragrance, and what a quiet spell it casts over one, inviting tired man to lay his troubles at the feet of Nature and be a care-free child again.

The light in the deep forest is a half twilight, like that in some mighty cathedral filtered through green stained-glass windows; only the light of the forest is purer than that of the temple.

Its carpets are as soft and luxuriant as those in the church. The foot sinks as 
noiselessly in the moss as in the most costly Persian rug. Its pattern, too, is infinitely more pleasing than that of the rug, for nature never repeats. You cannot find, no matter how long you search, one blade of grass that is quite like another. There is no fern frond but has some peculiarity all its own. God was not so busy when $\mathrm{He}$ fashioned the universe, that $\mathrm{He}$ could not find time to make a new pattern for each of His creations, no matter how tiny. Of all the countless number of snowflakes that have fallen to earth, the microscope has yet to discover two alike.

The incense in the woods is sweeter and more alluring than that of the church, for it teems with life. Each fragrance, each aroma, tells a story all its own; a story of life that throbs and yearns toward the light, that expands and fulfils its destiny.

The choristry in the woods is sweeter, more melodious than that in the church, 
for what human vocalist can chant like the hermit thrush? Not only do the birds sing, but a hundred little crawling, creeping things all have voices of their own; sweet little undertones and overtones in the great Te Deum.

Into this sanctuary of the Most High come the lumbermen in obedience to the call of commerce. From morn till night the ring of the axe resounds in the cathedral aisles of the woods. Huge sentinel pines and spruces, that have seen half a dozen generations of men come and go, totter upon their broad stumps and fall to earth, and "great is the fall thereof."

The ferns, the mosses, the creeping vines are ruthlessly crushed and killed. For green freshness and growth, there are left sawdust and chips, bleeding tree-stumps and death-death, dearth and desolation.

Go through the green woods in the summer before it has been despoiled, and 
then again the following spring in the wake of the lumbermen, and you will not recognize it as the same place. The tops of the fallen giants, which in their haste and greed the spoilers of the forest did not even limb out, are piled mountain high; while in every direction there is a tangle of dead limbs, chips, chip dirt, sawdust and treestumps.

Such were the conditions along the ten miles of trail that Roderick traversed every other day with the tote-team, the fourth autumn of his connection with the Ottawa Lumber Company. The trail led through two years' cuttings, farther on into the wilderness. But this autumn was quite different from anything that the young Scotchman had ever known, as far as nature and the woods and fields were concerned.

Usually there had been six inches or a foot of snow when he began his trips, but 
this year there was barely enough to make the ground white, and so Roderick had to use an old wood-shod sled, which would run smoothly where an iron-shod sled would scratch. Even this little snow disappeared the first warm day after its fall, and the ground was as dry and as crisp as it had been before.

No rain had fallen since the middle of August, and the country was in the clutches of the worst drought old lumbermen remembered ever experiencing.

In midsummer even the leaves had turned a sickly yellow, beginning with the trees upon the uplands, which usually turn latest. The ferns had also curled up their long graceful fronds into fantastic shapes, as though they had writhed and twisted in agony from the great thirst that was over all the land. Springs had gone dry that had never before failed in the memory of man. The smaller streams either had en- 
tirely dried up or had been reduced to a mere succession of pools, with rocks and sand between. The grass had withered to a brown crisp. It was so dry that the sheep had partially given up grazing, and had nibbled the leaves from bushes, which were slightly greener.

Dust was everywhere. It lay thick upon the dried grass and leaves. The walls and fences were covered with it. It was in the very air one breathed. The sun rose in a yellow haze and set in a blood-red sea of fire.

The birds and all the four-footed denizens of the fields were ill at ease. Mother Nature was sick, and all partook of her malady. The crow clan often flew home to roost in the spruces when the sun was still three hours high. The eagle wheeled ceaselessly in the troubled sky, and screamed when there was apparently nothing to cause alarm. One day a muskrat left his native 
stream, which had gone dry, and actually came into the village, where he ferociously attacked a peaceful pedestrian and would not desist until knocked senseless with a club. "He was mad," an old woodsman said. And who can wonder? When Nature herself has gone mad, what is left for her little furry children who are so dependent upon her caprices?

In the deep woods, or what had been the deep woods before the lumberman's axe swept it, the drought was still more apparent.

All summer long the gum and the turpentine had been oozing from stumps and the ragged ends of limbs; the chips and the chip dirt had been drying and baking. The myriad needles upon the dead tree-tops, no longer supplied with the life-giving sap, had turned sear and dry.

By November all the vast forest waste, that the lumbermen had left in their wake, 
was tinder. The dead leaves, the wrinkled fronds, the brittle, lifeless limbs, the pitchcovered stumps, the dry chip dirt,-all were like a powder mill ; impotent in themselves, yet holding in their impassive grains and fibres the power of a terrible holocaust.

Old lumbermen shook their heads and looked anxiously each day toward the cloudless sky. Both the sky and the earth had a ghastly appearance, that made even the most familiar places seem new and strange.

One morning when Roderick started on his trip to the Point, there was a strong gale blowing from the northeast, and this made the lumbermen more anxious than ever. Hairface was not in camp when the team left, and Roderick did not wait for him, knowing well that he would soon discover that he had gone, and would follow.

About half an hour afterward, the Cookee ran screaming and gesticulating from the 
mess-room. He was a little Frenchman and very excitable ordinarily, but now he seemed fairly beside himself. $\mathrm{He}$ waved his arms about his head shouting, "Py Gar, François done one pig fool ting. We all burn up for suah, now. Christus, Holy Mother, save us."

Even as he spoke a great cloud of smoke came pouring through the roof, almost immediately followed by a tiny flame, the red tongue of evil.

The Cookee had been frying doughnuts and the fat had caught fire. He had lost his head and pitched the kettle into the corner of the room which had been in flames almost before he could turn around.

For one second the tiny flame on the roof flickered and quivered, uncertain of its power, and then it felt the strong wind and knew that its hour had come.

Like a demon, a thing of life, it leaped ten feet into the air, sucking up a small whirl- 
pool of dust and powdered chips from the roof of the building; dust and chips which had been drying and baking all summer long in the scorching sun, and which already trembled and vibrated with warmth.

As the bright pillar of fire swept this cloud of dust into its great red mouth, it roared with triumph; it leaped and danced with glee; it hissed like some great serpentine fury that gloated over its prey so near at hand.

Again the monster leaped and this time an old weather-scarred pine above the messhouse caught. For five seconds the flames traveled uncertainly in the lower branches, and then, with a rush and an exultant whoop, sprang to the top of the tall tree, at once gaining the advantage of a crown fire. For a moment it burned bright in the tree-top, as though waiting for new strength after its climb; then, as a strong gust of wind struck it, leaped twenty-five feet into 
the air, roaring like an insensate thing. Like a red devil it towered above the surrounding tree-tops, hissing and spurting out greedy branch tongues of flame in every direction.

Lashing itself into double fury, this red rage of nature burned on, the life and the warmth of the world gone mad; the most terrible force in nature, before which men are as flies, once it sets its red seal of destruction upon the landscape.

At this point a dozen lumbermen came running breathless into camp. Their swarthy faces were white with fear. Their voices were hoarse with excitement and anger. They pointed, they gesticulated, yet were as helpless as the forest itself, while the great demon in the tree-tops leaped from sentinel pine to noble spruce, impartial in his fury, opening his great jaws of fire and engulfing an entire tree at a mouthful. 
There was not much immediate danger for the men. A strong gale was blowing, and they could go to the leeward of the fire; but the camp was doomed, and the cuttings of the two previous years would be swept clean,-God only knew how much more. It might sweep all the way to the Ottawa River with this gale behind it.

Just at this point in the development of this holocaust of nature, the tall gaunt form of Hairface came racing excitedly into camp. He ran first to the stable, and then to the trail leading to McGregor's Point. One sniff at the dry earth told him all that he wanted to know. Anxiously his wrinkled, hairy face was lifted to the lurid treetops, where the great pillars of fire leaped like red devils; they had felt the strong gale at their backs and had begun a mad race toward the Ottawa. From tree-top to tree-top they leaped, taking fifty feet at a jump, running like the wind behind them. 
In a swift second Hairface observed all these things. Then the tough sinews in his mighty frame became pliable, his whipcord muscles loosened, as he stretched his long racing length to mother earth and covered the trail toward McGregor's Point as only a mighty wolf could.

In the tree-tops above him the flames roared and hissed. Bits of burning twigs fell about him. The air grew unbearably hot. A thick smoke, like a sea of fog, rolled ahead of this sea of fire. It was verily the crack of doom. Nature was avenging herself upon impotent man for all his desecration of the ancient woods.

Meanwhile Roderick, all unconscious of the scourge that was galloping through the tree-tops behind him, was jogging slowly on his way to McGregor's Point. The first intimation that he had of danger behind was received when he mounted a rise in the trail which at this point passed over a 
ridge. As he came out upon the crest of the hill, he noticed a flock of crows flying over with great haste. The crow is usually a leisurely flyer, but these seemed in a great hurry; besides they were squalling excitedly. When they had passed, Roderick turned his head, and looked back along the way he had come.

To his amazement the entire horizon line in his rear was ablaze. The sheet of fire seemed fully a mile wide, and it was coming toward him at a pace that made his cheek pale as he gazed. Here and there tall pillars of fire told where a giant tree was being wrapped in its winding-sheet. These tall pyramids of fire leaped constantly from point to point, but always toward him. The smoke from the holocaust was barely half a mile away, and Roderick fancied that he could hear the roaring of the monster as it approached.

This fire must be rumning thirty miles an 
hour, he thought. With the wood-shod sled and the horse he could not make ten, but perhaps he might keep ahead of it on horseback. In less time than it takes to tell it, he had unhitched the animal and was upon his back, racing for dear life. He had picked up a stick as he sprang upon the horse and he now plied it with all his might, for it was a case of spare the rod and lose not only his life, but also that of the good steed.

The trail was very rough. The horse slipped and occasionally nearly floundered upon the treacherous leaves and the yielding moss. The harness, which he had not had time to make secure, flopped about ceaselessly. It was a mad race for life, with danger at every point. A misstep and a fall for horse and rider would be fatal.

Still another disadvantage was found in the fact that the trail was crooked. It did not always proceed directly away from 
the fire, but wound in and out through the most favorable ground. Yet the unblazed trail was so uncertain that Roderick dared not leave the beaten track to cut across country.

For ten minutes they sped on. Although he lashed the horse frantically, the fire gained steadily on them. The thick clouds of smoke that rolled for half a mile ahead of the whirlwind of flame were already about them. Now, he could hear the roar of the pursuing monster, and it was like that of a mighty cataract.

Occasionally a burning twig would fall across their path, catching the leaves upon the ground almost immediately, and these little outspurts of flame enabled the whirlwind to travel more rapidly.

The horse was now as much terrified as Roderick and needed no whip, but strained its every muscle. Each time the trail made a sharp turn or doubled back upon itself, 
Roderick groaned. Their lives might hang upon only a minute; for he felt sure that, once out of the cuttings of the past two years, the fire could not run so rapidly, and perhaps he could distance it if he could keep up this pace for four or five miles more.

But the roar of the flames behind grew louder all the time, the smoke in the air grew thicker, and the falling of sparks and bits of burning bark about them became more and more frequent. The cloud of smoke was now dense about them, and the great leaping pyramids of fire were barely half a mile behind.

Anxiously Roderick turned his head to get one more look at the advancing sea of fire, and to estimate his chances for life; and in that second of inattention to the trail and his flying steed, something happened that took away the slight fighting chance that he had possessed the moment before. 
At the instant that he turned his head, a low limb from a tree beside the trail, a limb such as he had been dodging all the way, caught him under the chin, and, as he was unprepared for it, the obstacle brushed him from the horse's back like a fly. The steed galloped frantically on, leaving him sprawling by the trail, dazed and uncertain. The horror of his situation soon aroused him, and in a moment he was up and after the flying horse. There was no hope of overtaking him; it was now a race on foot, but he must make the best fight that he could. So he set his teeth hard, leaned far forward, and ran as he had never run before.

Even at his utmost pace, which he could maintain for not over half a mile, the fire bore down upon him with alarming swiftness. The smoke grew more dense, sparks fell constantly, and the air thickened as though with the blackness of his doom. 
Deer, running with the speed of the wind, raced frantically by him. Foxes, belly to earth, stretched their supple limbs and sped by like red streaks. Large birds flew screaming overhead. The rabbit, terror lending wings to its usually fleet limbs, flashed by. Everything in earth and air seemed to be outstripping the poor man in his race for life.

Cold sweat stood upon his brow, and his breath came in quick gasps. Five minutes, yes, three minutes more and the flames would engulf him. Even now the smoke was so thick that he could hardly breathe or see, or was it partly the exertion he was making that dimmed his sight? Despair clutched the young man. It was awful to die like this ; a rat in a trap. To be burned to a crisp, like a brush heap, without being able to do a thing to save one's self was horrible. Was there no help in earth or heaven?

Then his toe caught under a projecting 
root, and he fell heavily. For a second he did not rise. What was the use anyhow? It was all over.

In this moment of uncertainty, when hope flickered and almost went out, a great gray shape sprang through the gloom and a cavernous mouth was closed upon his arm. The teeth did not sink in his flesh, but tugged frantically at his clothes, and a flash of intelligence like a bright flame illumined his brain. It was Hairface.

With a glad cry, Roderick sprang to his feet, and hope again leaped in his heart. $\mathrm{He}$ had a strange intuition that his good old friend had come in some miraculous way to save him. Else, why had God sent him in this hour of peril? But how the miracle was to be wrought he did not know.

He turned to flee along the trail and away from the fire, calling to Hairface to follow ; but the wolf-dog caught him by the sleeve and pulled him to one side, indicating 


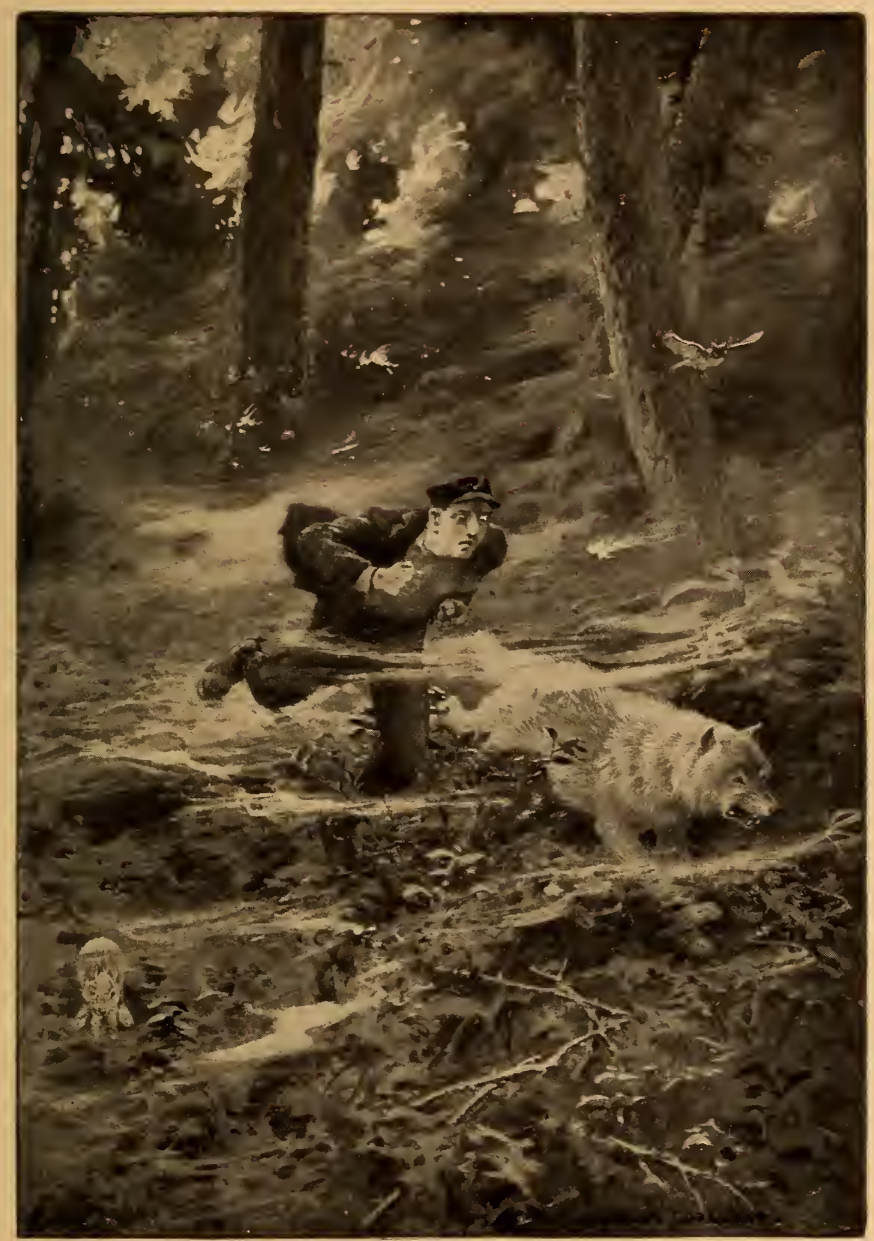

Frantically They Raced Through the Scorching Woods 
plainly that they should travel directly across the path of this whirlwind of flame.

Roderick hesitated, as the meaning of the dog's action dawned upon him. It was utter madness. They could not make half the fight in that direction that they could running straight ahead. Again he started along the trail, but this time Hairface in his insistence tore the sleeve from his coat. So the young man yielded to the dog's entreaties and took the direction indicated. Frantically they raced through the scorching woods, the burning twigs falling all about them, and the main army of flames only a furlong away.

Presently Roderick noticed that his feet sank deep in soft moss, and then, with a glad bark, Hairface, who was one jump ahead of his master, plunged into a small swamp pool, not over thirty or forty feet in length, and perhaps twenty wide. Roderick followed and hope, which dies hard in 
the young, again burned high, and the wonderful instinct of his wolf-dog was at once apparent to him.

Wilderness creatures from the beginning of time have taken refuge from forest fires in lakes and streams, and this was the best substitute for it that there was at hand.

To prove that it had been Hairface's wild instinct which had guided them hither, there was in the pool near by them another wolf, as well as a bear, a buck and two does, and half a dozen small creatures bobbing about uncertainly upon the water. It was surely a queer company that took refuge in this pool in the morass: the buck and his slayer, the gray wolf; the bear and his slayer, man, who is always looking for his coat. Truly the "lion and the lamb" were to "lie down together" upon this terrible day.

While Roderick looked, trying to make out in the darkness who were his strange 
companions, the smoke settled like a thick pall over everything and the heat grew almost unbearable. Sparks came down upon them in showers, and occasionally burning brands fell hissing in the pool.

Hairface was lying with his entire body submerged and only the tip of his nose showing, and his master followed his example. Surely his wild instinct was the best guide in such an extremity.

When the heat became so fierce that he could no longer stand it at the surface, Roderick would plunge his face under water, and when he could no longer breathe, he would come to the surface again for fresh air. But at such times the heat quickly drove him under. Finally he hit upon the expediency of covering his face with his cap, which had been drenched with water, and this partly protected him and at the same time gave him a chance to breathe. At best it was a frightful ordeal. The 
buck plunged frantically from time to time, as though about to break away and flee into the fire. The bear also was most uneasy, and waded from side to side of the pool, trying vainly to find a cool spot. Only the man, the wolf-dog, and the real wolf seemed to have intelligence enough to appreciate all the facts in the case.

For half an hour, and it seemed to Roderick like an eternity, they sweltered and choked, alternately ducking their heads under the water to escape the terrific heat, and then coming to the surface to inhale some of the smoke-thick air.

Hairface and Roderick kept side by side, and the wolf-dog occasionally snuggled up to his master as though to tell him that it was all right.

Finally the heat abated a little, although the smoke was still thick as night, and they could at last keep their heads above the water all the time. When they had lain 
for another hour in the seething pool, they came forth, covered with mud and grime, but safe.

Slowly they picked their way through the still smouldering forest, where the red rage had set its black seal upon everything. It was a desolate scene. Dearth was everywhere, but what did it matter as long as their lives had been spared? 
CHAPTER XI

THE WILDERNESS CALL 


\section{CHAPTER XI}

THE WILDERNESS CALL

Авоuт the first of February, when the wilderness was in the Titanic grip of old winter, when spruce and hemlock and laurel were snow-laden, when the throbbing of the very heart of nature had almost ceased because of the intense cold, Roderick and Hairface made their last trip together with the tote-team, although neither appreciated this fact as they wound in and out of the ghostly aisles of the forest.

There seemed to be some instinctive knowledge of coming separation in the mind of the wolf-dog, for he several times jumped upon the load and wriggled up as closely as he could to his master, as though he would fain express the great dog love 
that welled up in him, to the obliteration of all other feeling.

That night, when Roderick arrived home, he made the horse snug for the night as usual, and then reached under the seat of the pung for the little rifle which he always carried upon these trips and which had brought him many a partridge or rabbit as he threaded the forest aisles. The gun seemed to be caught in the horse-blanket, and the young man, holding the muzzle, pulled to free it. There was a sharp report and, without even a groan, Roderick fell forward upon the barn floor with a bullet in his heart.

With a spring Hairface was by his side, and his frantic howling and barking soon brought the boy's father to the scene. Help was at once summoned, and strong arms lifted Roderick and bore him into the house, where they laid him upon a bed. Hairface crowded as close as he could to 
the legs of the men as they carried his master, a look of unutterable anguish on his wrinkled, hairy face.

The doctor was brought immediately, but he needed only to place his hand upon the boy's wrist to read its pulseless story. Roderick was dead.

When the physician had gone, heartbroken Hairface took up his position by the bedside, and would not leave it except to allow some of the necessary things to be done for his dead master. He did not offer to lick his friend's hands or face, as he would have done, had the boy been alive; but simply rested his muzzle upon the pillow near his master's head. There he stood like a statue for hours, keeping a last death-watch by the one human being in all the world who had been kind to him, doing this reverence and love for his dead god, for Roderick had been as a god to him, all-. powerful, all-wise, all-beneficent. 
Toward morning the wolf-dog deserted his post for a few minutes and went out into the open, just as a man often does with his grief. A few seconds later a high-keyed, desolate howl, mournful as the moaning of the wind or the cries of the screech-owl, floated back into the room where the dead boy lay.

Roderick's old mother went to the window and saw poor Hairface, his long nose lifted toward the star-gemmed heavens, pouring out his grief to the pitiless night. His outcries were not full-throated, but half-stifled, and rose and fell like the sobbing of the night wind. Soon he returned and again took up his position at the side of his master.

The following day it was a sorry little procession that bore the body to the buryingground, where it was laid to rest. The sky was overcast and leaden, as though the very heart of Mother Nature ached, and as the 
funeral party wound their way up the hill to the churchyard, it began to snow.

When the minister had said, "Dust to dust, ashes to ashes," and the company were about to leave, Hairface sprang into the grave, as though he too would fain be covered up with his master. No amount of coaxing or threatening would make him come out. Some of the villagers wanted to shoot him, but Roderick's father would not hear of it.

"Let him alone," he said. "I know just how he feels. He will soon understand that it is of no use."

So they went away and left Hairface snuggling down as flat as he could upon the pine box that he knew contained his master. He knew, too, that his master was dead; he had seen death too many times not to understand. The spirit of darkness and of cold, that which numbs the earth and all its glad life, had taken him. But 
he was waiting a while, as the old Scotchman had said, until it should be quite plain to him.

About two o'clock in the morning, the villagers were awakened by long and heartrending howls from the hillside. Roderick's father went to the door and looked up at the little meeting-house, toward which his heart now yearned anew. The moon was at its full, and it was as light as day.

There upon a great black rock, which the wind had swept clear of snow, sat Hairface, his gray coat clearly outlined against the sky. His nose was pointed toward the moon, which was just setting, and the howls that floated down across the valley made the tears course afresh down the wrinkled cheeks of the old man.

The night before, when he had howled because of the death of his master, the cries had been partly smothered, as though he feared to disturb the rest of the mourn- 
ers with his grief; but now it was different. Out in the open, where there was no one to hear but the moon and the stars, he could pour out the full measure of his anguish in mighty howls that rent the stillness of the night. Sometimes these cries would rise to a high-keyed note, a mere thread of sound, and then would swell in volume, becoming deeper in tone, until they were a perfect roar of rage.

Others there were in the valley who heard the wolf-dog grieving for his master, and even those who had been most skeptical of Hairface now knew that he loved the man as truly as could have any dog.

While the great wolf-dog sat upon the boulder pouring out his anguish to the night, a subtle and mysterious change was going on inside of him. Fibre by fibre his dog heart was breaking. Drop by drop his dog blood was turning to wolf. Slowly the love light in his eyes, his dog heritage, 
faded, and the yellow gleam of the wolf took its place. The only man creature who had ever loved him was dead. The only link that bound him to civilization was broken, so why should he remain civilized? The houses of the man-creatures in the valley changed from the interesting abodes of those whom he loved to the hostile fortresses of those who hated him, and consequently whom he hated.

Gradually the note of lamentation in his howling changed to rage, rage at the fate which had given and taken away his god.

At last the giant wolf stretched his mighty form and stood upon all fours. $\mathrm{He}$ glowered down at the houses of men in the valley, and a deep growl rumbled in his throat. Henceforth these men creatures would shoot him at sight. Well, he would take care that they did not see him.

The keen winter wind blew sharply in his wrinkled face, but to him it was a tonic. 


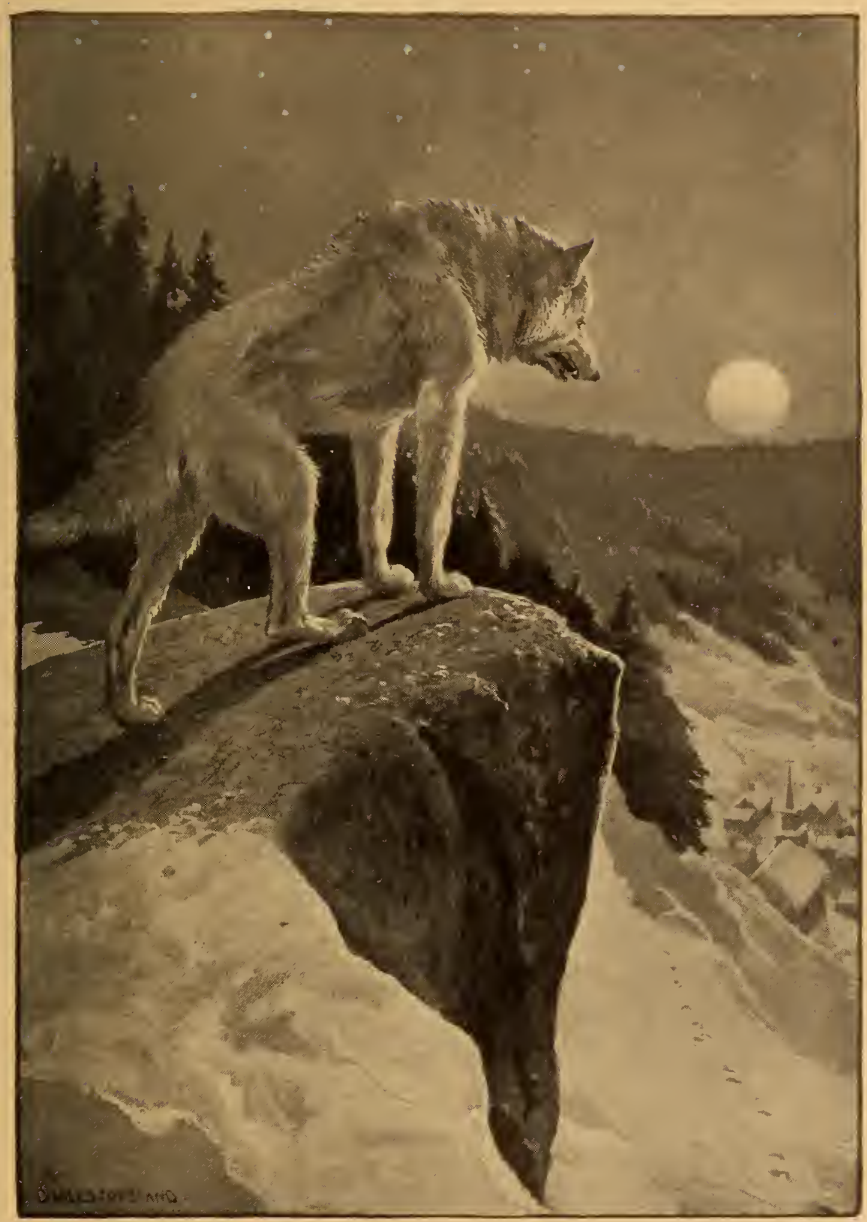

He Glowered Down at the Houses of Men in the Valley 
He drew long whiffs into his lungs, expanding his deep chest to its full dimensions. The wind tasted of spruce and of pine, of the laurel swamp where there was good rabbit hunting, and of the deep cover where the partridges were hiding this night.

In imagination the wolf saw the snowladen woods, with its moose and deer-yards, and its wild freedom. All were calling to him now. He had been a dog too long. Too long he had been upon the leash. $\mathrm{He}$ cast one last look at the sleeping valley and the haunts of man, and then sprang from the rock. Over the glittering crust he galloped, and, with each mile left behind, the blood quickened in his veins. It was a mad joy to feel the rush of the wind, the lash of the underbrush in his face, and the exhilaration of free flight. Little showers of ice went sliding in every direction as he ran, and the shy little wood- 
folk saw him pass with fear in their hearts.

He was galloping back to the old hunting-grounds of his sire, where he had first learned to catch mice, and where he had broken the back of his first fox. The bushes, the trees, the stumps, and even the rocks were calling to him.

Just at sunrise he came out upon the top of a high bluff, and against a background of evergreen saw a tall wolf waiting for him. His first impulse was to rush at the stranger and give battle, but he at once remembered. This was a wolf like himself; they were brothers in the wilderness. But were they brothers? He thought his nose said something different, so he approached the stranger warily.

The she-wolf waited his coming with apparent indifference, although the mating call was probably singing in her blood. Hairface went up and sniffed noses with 
her, and then he knew that it was she who had called him as he sat alone with his grief upon the rock above the valley where the men creatures lived. Once more the two sniffed noses, and the wolf-dog was certain that he would never again be a dog.

Then the twain turned and trotted off into the deep woods, going side by side. The wilderness dog had obeyed the call of his kind. A wolf he was born, and a wolf he must die. Henceforth his allegiance would be to his mate, his offspring, and also to the gray pack that hunted in the bluegreen depths of the ancient forest.

The wilderness at last had claimed its own. 


$$
\text { SEP }: 6+1=
$$





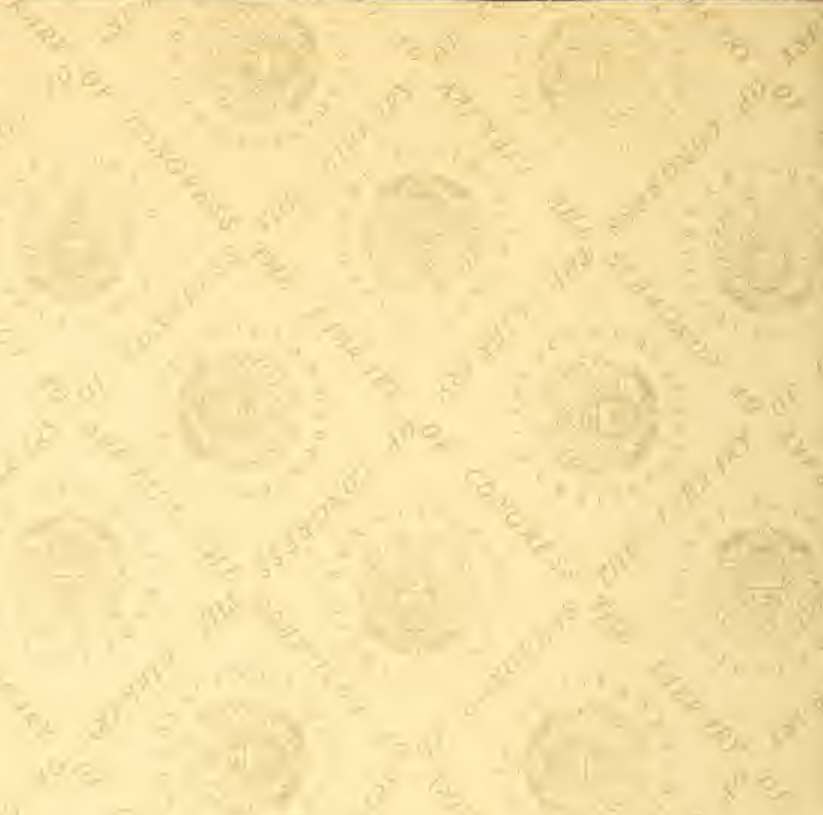





\section{LIBRARY OF CONGRESS}

||||||||||||||||||||||||| 00055065317 